\title{
System Justification Theory and Research: Implications for Law, Legal Advocacy, and Social Justice
}

\author{
Gary Blasi $\dagger$ \\ John T. Jost ††
}

\section{INTRODUCTION}

Both law and legal advocacy necessarily rest on assumptions about human motivation and behavior. Many of those assumptions are wrong. Just as scientific experimentation determined that Aristotle's physics did not accurately describe the behavior of objects, modern psychology and other social and behavioral sciences have determined that many common understandings of human behavior are, at the very least, incomplete.

Although there is no doubt that self-interest and group identification motivate human behavior, recent scientific research has revealed a quite different and often powerful motive: the motive to defend and justify the social status quo, even among those who are seemingly most disadvantaged by it. System Justification Theory (SJT) explains the contours of this motive and the contexts in which it operates. Our aim in this Article is to demonstrate that SJT has important implications for law, lawyering, and advocacy for social justice.

SJT has implications for law because system justification motives sometimes result in behaviors that current legal thinking would not otherwise anticipate. For example, victims of discrimination or abuse complain less often than individual and collective self-interest would predict, and

Copyright C 2006 California Law Review, Inc. California Law Review, Inc. (CLR) is a California nonprofit corporation. CLR and the authors are solely responsible for the content of their publications.

$\dagger \quad$ Gary Blasi, Professor of Law, University of California Los Angeles School of Law.

i† John T. Jost, Associate Professor of Psychology, New York University. We have benefited greatly from conversations with members of the behavioral realism working group, including Ian Ayres, Mahzarin Banaji, Susan Fiske, Anthony Greenwald, Jerry Kang, and Linda Hamilton Krieger. We also thank Rick Banks, Irina Feygina, Mark Fondacaro, Curtis Hardin, Orsolya Hunyady, Alison Ledgerwood, Ido Liviatan, HuIda Thorisdottir, Tom Tyler, and Jojanneke van der Toorn for helpful comments on earlier drafts of this Article. We are grateful to Cynthia Duffy, Cara Jolly, and Sara Jackson for research and other assistance and to New York University and the Hugh and Hazel Darling Law Library at UCLA for generous support. Finally, we gratefully acknowledge support from the Russell Sage Foundation and the Radcliffe Institute for Advanced Study at Harvard University. 
employees conceal evidence of corporate wrongdoing even when rational self-interest would counsel otherwise. SJT also has implications for lawyers and other advocates. It recommends, for example, that lawyers attend to all potentially relevant social orderings in selecting jurors and developing advocacy strategies. The theory also speaks to the persuasive power of "framing," and suggests how advocates can deploy narrative to amplify or dampen the system-justifying motives of those whom they would persuade. Finally, SJT identifies important obstacles to social change in general, as well as to change in law and legal scholarship. Law, lawyers, and legal scholars need to take seriously the research on system justification motives and processes.

Our project is deeply rooted in the project of behavioral realism. ${ }^{1} \mathrm{~A}$ behavioral realist approach to law posits that law can better realize its normative aims if it is based on an accurate view of how individuals behave and how social institutions function. Just as our colleagues in this Symposium demonstrate that knowledge about the effects of implicit bias requires a rethinking of antidiscrimination law and practice, this Article argues that knowledge about system-justifying motives requires a re-examination of important aspects of law and legal advocacy.

Our project of behavioral realism continues an important tradition. Academic law has attempted in various ways to bring to law the insights of the behavioral sciences. Law and economics relies on an explicit psychology of rational choice, in part because more complex psychologies are beyond the capacity of current mathematical models. Homo economicus is a very useful but not entirely valid scientific model. Behavioral law and economics has attempted to bring to law and economics what social science tells us about behavior. ${ }^{2}$ A great deal of legal scholarship has taken the rational choice model as the default, and has explored the legal implications of specific violations of this model. ${ }^{3}$ However, some contemporary psychologists and legal scholars seek to develop process models of human thinking and behavior ${ }^{4}$ that rest on more complete, empirically satisfying

1. The phrase "behavioral realism" was coined in an informal gathering that led to the interdisciplinary project of which this Article and Symposium issue are a part. For the earliest published report of the enterprise, see Jerry Kang, The Trojan Horses of Race, 118 HARv. L. REV. 1489,1494 n.21 (2005).

2. To be sure, not every scholar in the field would agree with this characterization. The literature in behavioral law and economics is too extensive for us to provide a definitive set of references. For an excellent introduction, see Behavioral LaW and Economics (Cass R. Sunstein ed., 2000).

3. Another effort at reconciling law and soeial science has been called "empirieal legal realism" or "law and behavioral scienee." See, e.g., Mark Kelman, Law and Behavioral Science: Conceptual Overviews, 97 Nw. U. L. REv. 1347 (2003).

4. Although this Article and the others in this Symposium are primarily focused on the level of individual and social psychology, we recognize that analyses on other levels-societal, institutional, and structural-are essential to a complete understanding of situated human behavior and the overall projeet of behavioral realism. 
foundations, and then explore the consequences of these models for law and lawyering. In this Article, we travel part of the way down this path.

We begin with some of the evidence for a fundamental human motivation to defend, justify, and bolster the social status quo. This system justification motive interacts with other motives to produce sometimes surprising results. Consider the following examples.

\section{A. Evidence of a System Justification Motive}

\section{Anticipatory Rationalization of the Status Quo}

In one widely observed phenomenon, people begin to shift preferences toward future social and political arrangements as those arrangements become increasingly likely. For example, in the week before the presidential election of 2000, a group of researchers at Stanford University ${ }^{5}$ provided 288 adults of diverse political persuasions with one of five bogus, but credible, "expert predictions" about the election, ranging from a $51 / 43 \%$ victory for Gore to a $51 / 43 \%$ victory for Bush. Researchers then asked all study participants to rate the personal desirability of a Bush or Gore presidency. Both Democrats and Republicans showed a "sour grapes" tendency to rate their party's candidate as less desirable as his election appeared less probable. ${ }^{6}$ In addition, partisans of both stripes exhibited a "sweet lemon" tendency to rate the candidate of the other party more highly as his election seemed more probable. By contrast, Independents and nonpartisans showed no comparable tendency to rationalize the anticipated status quo, presumably because they were less engaged in the outcome of a Bush versus Gore contest. ${ }^{7}$

\section{Preferring the "Other"}

Both lay people and psychologists often assume that people prefer those who share a group identity and are thus in some respects similar to themselves. Yet numerous studies show that members of disadvantaged groups often prefer members of other, more advantaged groups. For example, in one study, researchers asked Latino, Asian American, and White students in a UCLA social psychology class to sign up for a "getting acquainted study" and provided students with a photocopy of a sign-up sheet ostensibly filled out by students in another class section. The bogus sign-up sheet included available slots to partner with students with surnames of

5. Aaron C. Kay et al., Sour Grapes, Sweet Lemons, and the Anticipatory Rationalization of the Status Quo, 28 Personality Soc. Psychol. BUll. 1300 (2002).

6. Id. at 1305-06.

7. Id. at 1306 . 
Latino, Asian American, and "White" origins. ${ }^{8}$ Students from all three ethnic backgrounds were significantly more likely than chance would predict to select time slots that matched them up with "White" partners. ${ }^{9}$ This is but one of dozens of studies demonstrating that members of socially disadvantaged groups harbor preferences of one kind or another for members of dominant or advantaged groups. ${ }^{10}$

\section{Shifting Stereotypes in Response to System Threat}

Stereotypes often help to maintain hierarchical social arrangements. Studies show that when people perceive a threat to the legitimacy or stability of the social system to which they belong, they rely increasingly on stereotypes to bolster the status quo. In one study, American participants read one of two excerpts of a newspaper story purportedly written by a local journalist. One excerpt described the United States as being in serious trouble and in decline. ${ }^{11}$ The other described the national system in more favorable terms. ${ }^{12}$ Later, ostensibly as part of an unrelated study, researchers asked the same participants to rate two groups, powerful people and overweight people, on the following traits: independence, intelligence, happiness, laziness, and sociability. ${ }^{13}$ Whether participants had read the high or the low system-threat passage had a significant effect on their stereotyping of both powerful people and overweight people. Those exposed to the system-threatening scenario rated powerful people as more

8. John T. Jost et al., Non-Conscious Forms of System Justification: Implicit and Behavioral Preferences for Higher Status Groups, 38 J. ExPERIMENTAL Soc. Psychol. 586, 593 (2002).

9. Id. at $594 \mathrm{fig} .1$ (finding that Latinos and Asians chose to interact with in-group members only $25-27.1 \%$ of the time, which was significantly below the $33 \%$ standard that one would expect on the basis of chance; members of all three groups revealed a significant preference for interacting with White partners).

10. Often these preferences result from "implicit attitudes," which are attitudes suggested or revealed indirectly through behavior and are not necessarily consciously accessible. For a more thorough exposition of the theory and evidence regarding implicit attitudes and related concepts, see Anthony Greenwald \& Linda Hamilton Krieger, Implicit Bias: Scientific Foundations, 94 CALIF. L. Rev. 945, 948-52 (2006).

11. The excerpt read as follows: "These days, many people in the United States feel disappointed with the nation's condition. Many citizens feel that the country has reached a low point in terms of social, economic, and politieal factors. ... It seems that many countries in the world are enjoying better social, economic, and political conditions than the U.S. More and more Amerieans express a willingness to leave the United States and emigrate to other nations." Aaron C. Kay et al., Victim Derogation and Victim Enhancement as Alternate Routes to System Justification, 16 PsYcHOL. SCl. 240,241 (2005).

12. This excerpt read:

These days, despite the difficulties the nation is facing, many people in the United States feel safer and more secure relativc to the past. Many citizens feel that the country is relatively stable in terms of soeial, economic, and political factors.... It seems that compared with many countries in the world the social, economic, and political conditions in the U.S. are relatively good. Very few Americans express a willingness to leave the United States and emigrate to other nations.

Id. at 242 .

13. Id. 
intelligent and independent but less happy, and they rated overweight people as lazier but more sociable. ${ }^{14}$

\section{B. Introducing System Justification Theory}

What might account for these disparate and counterintuitive findings? Although each of these phenomena might have more than one determinant, these and many other research findings are consistent with the hypotheses of SJT. The theory, first advanced by Jost and Banaji in $1994^{15}$ and supported by scores of studies in the decade since, ${ }^{16}$ posits a general human tendency to support and defend the social status quo, broadly defined. How such a motive is expressed in attitudes and behavior will, of course, vary by individual and situation. But Jost and Banaji suggested that the familiar motives of ego justification (or self-interest) and group justification (or ingroup favoritism) were insufficient to account for many phenomena observed both in the real world and in the psychologist's laboratory. Among these phenomena are the many instances in which those who are seemingly disadvantaged by a social system become its most ardent supporters. ${ }^{17}$

Support for the system can be manifested in several ways. For example, stereotypes can help justify systems by suggesting reasons that [intelligent, hardworking] people are at the top and [lazy, irresponsible] people are at the bottom. In cultures in which egalitarian ideals are contradicted by what people see around them, "complementary" stereotypes (e.g., "poor but happy-go-lucky," "rich but miserable") can also help reduce perceived injustice and the dissonance between egalitarian ideals and observed realities. ${ }^{18}$ Notably, individuals need not do all of the cognitive work required to reduce this dissonance on their own. Stereotypes and ideologies supply ready-made justifications, explanations, and excuses for the system.

Much as ego justification motives become more pronounced when our self-esteem is threatened, causing us to become "defensive," system justification motives become most evident when we perceive a threat to the legitimacy of a system to which we are attached. These processes may produce seemingly irrational outcomes. Why should we become more prejudiced toward overweight people and more deferential to the powerful when we read a passage criticizing the United States? SJT demonstrates

14. Id. at 243 .

15. John T. Jost \& Mahzarin R. Banaji, The Role of Stereotyping in System Justification and the Production of False Consciousness, 33 BRIT. J. Soc. Psychol. 1 (1994).

16. See John T. Jost et al., A Decade of System Justification Theory: Accumulated Evidence of Conscious and Unconscious Bolstering of the Status Quo, 25 POL. PsychoL. 881 (2004).

17. See John T. Jost et al., Social Inequality and the Reduction of Ideological Dissonance on Behalf of the System: Evidence of Enhanced System Justification Among the Disadvantaged, 33 Eur. J. Soc. PsYchOL. 13 (2003)

18. See Aaron C. Kay \& John T. Jost, Complementary Justice: Effects of "Poor but Happy" and "Poor But Honest" Stereotype Exemplars on System Justification and Implicit Activation of the Justice Motive, 85 J. Personality \& Soc. Psychol. 823 (2003). 
that cognitive and motivational processes, many of which are outside of conscious awareness and control, affect our behavior under these circumstances. This work therefore goes beyond both rational choice theory and more traditional social psychological approaches.

Social systems that engender psychological attachment range from dyadic relationships and family systems to much larger work organizations and societal institutions. The property of "systematicity" implies that there exists some sustained differentiation or hierarchical clustering of relations among individuals or groups within the social order. SJT suggests that people are motivated to accept and perpetuate features of existing social arrangements, even if those features were arrived at accidentally, arbitrarily, or unjustly.

However, people will not always or unequivocally support the status quo; indeed, ego or group justification motives can outweigh the system justification motive in certain circumstances. For example, "identity politics" can make group justification motives more salient, and these motives may come to outweigh the system justification motive. Moreover, people can be seen, and can see themselves, as situated within multiple, overlapping systems. The importance of one system or another, whether a family system, religious code, industry practice, organizational structure, union rules, or the broader socioeconomic or political system, can vary over time. On occasion, justification of an ascendant (or perhaps utopian) system can replace justification of the current system. This process may be at work in the ideologies of radical social movements.

Moments of radical change, however, are exceptional. Most of the time, people have a general, inherently conservative tendency to accept the legitimacy of whatever "pecking order" is in effect and to perceive existing institutions and practices as generally reasonable and just, at least until this is proven otherwise. To paraphrase the essential lesson of Melvin Lerner's groundbreaking book on the "belief in a just world," human psychology is such that we tend to assume that people (including ourselves) get what they deserve and deserve what they get. ${ }^{19}$

\section{System Justification Theory and Law}

Some of the phenomena associated with SJT are well known both to the general culture and to law. After all, observations about "sour grapes" extend at least as far back as the time of Aesop. But common sense and lay psychology do not predict many of the phenomena hypothesized and explained by SJT. To the extent that law and lawyering depend on these nonscientific understandings of human psychology and behavior, both are likely to go seriously wrong at times.

19. Melvin J. Lerner, The Belief in a Just World: A Fundamental Delusion (1980). 
Evidence of system-justifying biases, which we will summarize in this Article, poses challenges to the established practices of lawyers and advocates for social justice as well as to many areas of legal doctrine. Advocacy strategies that do not take system justification motives into account may be ineffective or counterproductive, whether in the context of picking a jury and framing an opening argument or planning a public policy strategy aimed at improving public schools. SJT is also useful for understanding, and responding to, the challenges inherent in organizing underprivileged populations and the intense resistance that typically accompanies progressive public policy initiatives. Finally, SJT suggests the reasons it may be difficult for many, including those in the academy, to fully accept wellfounded but sometimes counterintuitive theories of human behavior-like those described in this and the other articles in this Symposium-that are seriously at odds with dominant models of rational choice. In this Article, we build on a few recent attempts to bring SJT and related research to bear on legal scholarship, in the hope that others will join us. ${ }^{20}$

This Article proceeds as follows. In Part 1 we provide an overview of theory and research on the system justification motive and its relation to other social psychological motives. Then, in the second half of the Article, we examine the implications of SJT for law and lawyers. Part 11 focuses on the means by which lawyers and other practicing advocates can take appropriate account of the system justification motive, whether in a courtroom or in the broader arenas of public policy debates and social movements. Part III explores some possible implications of SJT for policy and legal doctrine in two areas: claiming or reporting rates for torts and crimes, and the regulation of corporate insiders and auditors. In Part IV we offer some thoughts on the implications of SJT for the project of behavioral realism itself. We hope that this Article will help lawyers and other advocates refine their work and also stimulate others to join the project of exploring the consequences of system-justifying biases.

20. For recent articles on the subject see Jon Hanson \& David Yosifon, The Situational Character: A Critical Realist Perspective on the Human Animal, 93 Geo. L.J. I, 5 (2004) (providing the most complete account of SJT in service of the goal of "retiring the now-dominant 'rational actor' model of human agency," but failing to suggest implications for law of SJT's deviations from the "rational actor" model); Kang, supra note 1 (examining the implications of SJT for efforts to counter the effects of implicit bias); Antony Page, Batson's Blind-Spot: Unconscious Stereotyping and the Peremptory Challenge, 85 B.U. L. REv. 155 (2005) (citing Jost \& Banaji, supra note 15, not in relation to the theory itself, but in relation to implicit bias); Michelle A. Travis, Recapturing the Transformative Potential of Employment Discrimination Law, 62 WASH. \& LEE L. REV. 3, 20 (2005) (making extensive use of SJT in explaining why those disadvantaged by employment practices "internalize[] the status quo"). 
The Science: Fundamentals of Theory and Research

In this Part, we summarize the fundamental tenets and research findings of SJT for a legal audience. First, we discuss the notion that there is a general motive to defend and justify the status quo, comparable in strength and social significance to the parallel motives of ego and group justification. We then review some of the most significant empirical manifestations of system justification, focusing on rationalization of the status quo, the contents of stereotypes, and the internalization of inequality. Next, we describe several moderators of the basic system justification tendency, including individuals' personality dispositions (dispositional factors) and aspects of the environment or situation (situational factors). Finally, we discuss some social and psychological consequences of system justification, including the palliative effects of ideology and the implications for social change.

\section{A. The System Justification Motive}

\section{Why is the Appeal of the Status Quo so Great?}

The puzzling attraction of the status quo, not merely for its beneficiaries, but also for its apparent victims, provided the initial impetus for the development of SJT. ${ }^{21}$ What inhibits those who are disenfranchised by the status quo from denouncing the system and working toward a better one? What processes allow those who are privileged by the status quo to suppress the guilt and dissonance that might otherwise be evoked by the suffering of those who are less privileged? In attempting to understand these questions, SJT posits that, to varying degrees depending upon both situational and dispositional factors, people are motivated to defend, justify, and rationalize the societal status quo. ${ }^{22}$

The existence of a system justification motive accounts for people's affinity for a number of interrelated belief systems that have been studied (in some cases for decades) by sociologists and psychologists. These include the Protestant work ethic, ${ }^{23}$ the belief in a just world, ${ }^{24}$ meritocratic

21. For the first statement of the theory, see Jost \& Banaji, supra note 15.

22. See John T. Jost \& Orsolya Hunyady, Antecedents and Consequences of System-Justifying Ideologies, 14 Current Directions Psychol. SCI. 260 (2005); Jost et al., supra note 16, at 912 ("[S]ystem justification motives are sometimes capable of overriding ego and group justification motives associated with the protection of individual and collective interests and esteem."); John T. Jost et al., Political Conservatism as Motivated Social Cognition, 129 Psychol. BulL. 339, 350-51 (2003).

23. See Adrian furnham, The Protestant Work Ethic: The Psychology of WorkRelated Beliefs and Behaviours (1990); Christian S. Crandall, Prejudice Against Fat People: Ideology and Self-Interest, 66 J. Personality \& Soc. Psychol. 882 (1994); Norman T. Feather, Protestant Ethic, Conservatism, and Values, 46 J. Personality \& Soc. Psychol. 1132 (1984); Diane M. Quinn \& Jennifer Crocker, When Ideology Hurts: Effects of Belief in the Protestant 
ideology, ${ }^{25}$ power distance, ${ }^{26}$ right-wing authoritarianism, ${ }^{27}$ social dominance orientation, ${ }^{28}$ economic system justification, ${ }^{29}$ and fair market ideology. ${ }^{30}$ Each of these belief systems imbues existing social, economic, or political arrangements with legitimacy. They serve, in other words, a system justifying function.

ldeological belief systems supply ready-made rationalizations for aspects of the status quo that individuals feel compelled to defend and justify. ${ }^{31}$ Thus, a good deal of research we summarize in this Article has addressed the role of the system justification motive in supporting shared ideologies such as political conservatism and large-scale institutions such as capitalism, American society in general, and the gendered division of labor in families. ${ }^{32}$ SJT therefore helps to explain the overall tilt toward

Ethic and Feeling Overweight on the Psychological Well-Being of Women, 77 J. Personality \& Soc. PSYCHOL. 402 (1999).

24. See LERNER, supra note 19; John T. Jost \& Diana Burgess, Attitudinal Ambivalence and the Conflict Between Group and System Justification Motives in Low Status Groups, 26 Personality Soc. Psychol. Bull. 293 (2000); Zick Rubin \& Letita Anne Peplau, Who Believes in a Just World, 31 J. Soc. IsSUES 65 (1975).

25. See James R. Kluegel \& Eliot R. Smith, Beliefs About Inequality: Americans' VIEWS OF What Is AND What Ought to BE (1986); Jost et al., supra note 17; Brenda Major, From Social Inequality to Personal Entitlement: The Role of Social Comparisons, Legitimacy Appraisals, and Group Membership, 26 Advances in Experimental Soc. Psychol. 293 (1994); Joanne Martin, The Tolerance of Injustice, in 4 Relative Deprivation and Social Comparison: The Ontario SYmposium 217 (James M. Olson et al. eds., 1986).

26. See Geert Hofstede, Cultures and Organizations: Software of the Mind (1997); Joel Brockner et al., Culture and Procedural Justice: The Influence of Power Distance on Reactions to Voice, 37 J. Experimental Soc. Psychol. 300 (2001); John T. Jost et al., Fair Market Ideology: Its Cognitive-Motivational Underpinnings, 25 RES. IN ORG. BeHAV. 53 (2003).

27. See T.W. Adorno et al., The Authoritarian Personality (1950); Bob Altemeyer, The Authoritarian Specter (1996); Bob Altemeyer, The Other "Authoritarian Personality", 30 Advances in Experimental Soc. Psychol. 47 (1998).

28. See Jim Sidanius \& Felicia Pratto, Social Dominance (1999); John T. Jost \& Erik P. Thompson, Group-Based Dominance and Opposition to Equality as Independent Predictors of SelfEsteem, Ethnocentrism, and Social Policy Attitudes among African Americans and European Americans, 36 J. Experimental Soc. Psychol. 209 (2000); Jennifer R. Overbeck et a1., Resistant Versus Acquiescent Responses to Ingroup Inferiority as a Function of Social Dominance Orientation in the USA and Italy, 7 Group Processes \& InTergroup Rel. 35 (2004); Felicia Pratto et al., Social Dominance Orientation: A Personality Variable Predicting Social and Political Attitudes, $67 \mathrm{~J}$. Personality \& Soc. Psychol. 741 (1994).

29. See Jost \& Thompson, supra note 28.

30. See Jost et al., supra note 26 .

31. This notion of ideology is congenial to the explanation proffered in J. M. BaLKIN, Cultural SofTWARE: A THEORY OF IDEOLOGY (1998), as well as the original meaning of the term developed by Marx and Engels, Karl Marx \& Frederick Engels, The German Ideology (R. Pascal ed., 1970) (1846).

32. See, e.g., John T. Jost \& Aaron C. Kay, Exposure to Benevolent Sexism and Complementary Gender Stereotypes: Consequences for Specific and Diffuse Forms of System Justification, 88 J. Personality \& Soc. Psychol. 498 (2005) (attitudes toward the division of labor in families); Jost \& Thompson, supra note 28 (opposition to equality); Jost et al., supra note 26 (support for capitalism); Jost et al., supra note 22 (political conservatism); Kay \& Jost, supra note 18 (attitudes toward American society in general). 
conservatism in public opinion, even among segments of the population that would benefit from more liberal policies. In addition, experimental studies demonstrate that system justification operates even in short-lived, experimentally created social orders, in which groups are defined as "winners" and "losers" in a competitive simulation or status comparison. ${ }^{33}$

System justification processes appear to operate at both the explicit level of conscious awareness (as indicated by responses to opinion questionnaires) and the implicit or unconscious level of awareness (as indicated by reaction time and other indirect measures). ${ }^{34}$ People may not even be aware of the extent to which they are privileging the status quo and resisting change. Extensive research by John Bargh, Peter Gollwitzer, and their colleagues has demonstrated that goals can be activated outside of an individual's awareness, and that these goals will then guide the individual's behavior. ${ }^{35}$ For example, students exposed to positive words like win, compete, strive, attain, or master perform at higher levels on a subsequent word-search puzzle than students exposed to neutral words like building, staple, or turtle. ${ }^{36}$ Subjects exposed to words like helpful, cooperative, tolerant, or fair behave more cooperatively in a potentially competitive resource-allocation game than subjects exposed to neutral words like purposeful, switch, lead, mountain, and zebra. ${ }^{37}$

Some forms of system justification, such as stereotyping and discrimination directed against members of low-status groups, are not always normatively acceptable and may therefore be minimized in public or otherwise actively suppressed. Additionally, members of disadvantaged groups may suffer negative consequences from an explicit acknowledgment of their own or their group's inferiority. Thus, certain expressions of system justification, including outgroup favoritism, may be especially likely to arise implicitly rather than explicitly.

33. See, e.g., John T. Jost, Outgroup Favoritism and the Theory of System Justification: A Paradigm for Investigating the Effects of Socioeconomic Success on Stereotype Content, in CoGNITIVE Social Psychology: The Princeton Symposium on the Legacy and Future of Social Cognition 89 (Gordon B. Moskowitz ed., 2001); John T. Jost \& Orsolya Hunyady, The Psychology of System Justification and the Palliative Function of Ideology, 13 Eur. REv. OF Soc. Psych. 111 (2002).

34. We use the terms "implicit" and "explicit" here and throughout this Article in their technical sense, explained in greater detail in the companion article by Greenwald \& Krieger, supra note 10, at 947-48. To simplify somewhat, explicit thoughts and attitudes are those available to introspection and commonly assessed by means of questionnaires. $1 \mathrm{mplicit}$ attitudes are not accessible to introspection and thus are not captured on responses to questionnaires. They are, however, revealed in behavior, as in the response latency behavior at the heart of the Implicit Association Test, discussed in detail in Greenwald. Id. at 952-55.

35. See, e.g., John A. Bargh \& Tanya L. Chartrand, The Unbearable Automaticity of Being, 54 Am. Psychol. 462 (1999); John A. Bargh, et al., The Automated Will: Nonconscious Activation and Pursuit of Behavioral Goals, 81 J. Personality \& Soc. Psychol. 1014, 1017 (2001).

36. Bargh et al., supra note 35, at 1016-17 (Study 1).

37. Id. at 1018-19 (Study 2). 


\section{The Interplay of Ego, Group, and System Justification Motives}

SJT posits that both advantaged and disadvantaged members of the social order will participate in system-justifying behaviors, although their behaviors might take different forms. To get at these differences in the experiences of members of advantaged and disadvantaged groups, Jost and Banaji distinguished among three different justification tendencies that have the potential to be in conflict with one another. The first is ego justification, a general (though not ubiquitous) tendency to maintain or increase personal self-esteem and to perceive the world and behave in ways that are self-serving. ${ }^{38}$ The second motive is group justification, a tendency to hold and express more favorable attitudes about groups to which an individual belongs (i.e., "ingroups") in comparison with other groups ("outgroups"). ${ }^{39}$ To these two well-established and uncontroversial propositions, SJT adds a third: people also possess an independent system justification motive to defend and justify systems of which they are a part, even if their position within those systems creates a conflict or contradiction among ego, group, and system justification motives. SJT research explores not only the evidence for the existence of the system justification motive (and its motivational basis), but also how the system justification motive interacts with other competing motives to affect attitudes and behavior.

ln systems in which there are clear winners and losers, system justification processes manifest themselves somewhat differently for these two types of groups. Unencumbered by cognitive dissonance arising from their happy circumstances, winners can effectively narrate some version of a Panglossian story: "1 am deserving. My group is deserving. And, fortunately, we live in a system that has the wisdom and justice to reward deserving people. After all, we live in the best of all possible worlds." For

38. There is a voluminous literature documenting self-serving biases in a wide range of domains. See, e.g., Shelley E. Taylor \& Jonathon D. Brown, Illusion and Well-Being: A Social Psychological Perspective on Mental Health, 103 PsYcHOL. BulL. 193 (1988). Ego justification is fairly associated with the core assumptions of rational choice theory as well as with the phenomenon of "self-serving bias." For evidence that some people (especially people who are depressed or low in self-esteem) do not show self-serving biases, see William B. Swann, Jr. et al., Why People Self-Verify, 62 J. Personality \& Soc. Psychol. 392 (1992).

39. There are dozens of studies demonstrating ingroup (vs. outgroup) bias on both implicit and explicit measures. See, e.g., Marilynn B. Brewer, Ingroup Bias in the Minimal Intergroup Situation: $A$ Cognitive-Motivational Analysis, 86 PsYCHOL. BulL. 307 (1979). The group justification motive is associated with much familiar, and often troubling, behavior involving memhers of different social groups. For these purposes, "groups" can be of the familiar racial, national, gender, or religious variety, but they can also be "minimal groups" created by entirely artificial means. For example, in one experiment subjects who were told that they had either a concave or a convex "typc of attention sequence" (an entirely imaginary construct) nevertheless developed a preference for members of the same imaginary group. See Sabine Otten \& Dirk Wentura, About The Impact Of Automaticity in the Minimal Group Paradigm: Evidence From Affective Priming Tasks, 29 EUR. J. Soc. PsYCHOL. 1049 (1999). These general biases in favor of ingroups and against outgroups (even those that exist solely in the mind) exist at both implicit and explicit levels and significantly affect behavior. The "minimal group" effect is well documented across a range of classic studies in social psychology. 
winners in the system, the only source of potential dissonance comes from the unjustified suffering of losers. For most people, explanations come fairly easily: "The losers are undeserving; they are lazy, unintelligent, poorly educated, or irresponsible." They have preserved the legitimacy of the system and satisfied the system justification motive.

Those who are relatively disadvantaged in the system, the "losers," face greater psychological challenges, because dissonance arises from conflict among ego, group, and system justification motives. If individuals had no system justification motives, then anyone who was disadvantaged on either an individual or group basis would, given the slightest opportunity, challenge the system and reject it as unfair and exploitative: "I am deserving. My group is deserving. If we are suffering, then it must be the fault of others or the system in which we are trapped." Empirical observation reveals that disadvantaged groups rarely respond in this way to the problems they face. ${ }^{40}$ Instead, people commonly reduce ideological dissonance by other means, suggesting that they are motivated not only to hold favorable attitudes about themselves and their fellow group members but also to hold favorable attitudes about the overarching system.

Because system justification is consistent with self-interest for people who are advantaged by the status quo but is inconsistent with self-interest for the disadvantaged, members of advantaged groups are often (but by no means always) the most enthusiastic supporters of the status quo. ${ }^{41}$ Nevertheless, especially stark forms of inequality can create a discrepancy between the need to justify the system and the need to feel good about oneself and one's fellow group members. Under such circumstances, the cognitive dissonance that is created by the discrepancy between reality (e.g., widespread disparities in wealth) and one's beliefs about the system ("the economic system is fair") cannot be resolved easily by rationalizing one's own behavior ("I work hard and get paid very little but I enjoy it"). Rather, an ideological rationalization on behalf of the system is necessary in order to alleviate emotional discomfort: "The system is legitimate and works well because it rewards education, ability, and motivation. Unfortunately, I never did well in school . .."42

40. For historical accounts stressing the infrequency of protest and revolt, see BARRINGTON Moore, JR., Injustice: The Social Bases of Obedience and Revol. (1978) and Howard Zinn, Disobedience and Democracy: Nine Fallacies on Law and Order (1968). For examples in political science and psychology, see Rober' E. Lane, Political ldeology: Why the American Common Man Believes What He Does (1962) and Jost et al., supra note 16.

41. See, e.g., Sidanius \& PRATto, supra note 28.

42. SJT differs from Festinger's well known theory of cognitive dissonance. See LEON Festinger, A Theory of Cognitive Dissonance (1957). According to cognitive dissonance theory, people will resolve dissonance in whatever manner is easiest or (according to some later versions) in whatever manner is self-serving. See id. SJT, by contrast, suggests that people will disproportionately resolve dissonance in a system-justifying manner that might well be self-threatening (e.g., poor people 
In any given case, of course, the rationalization may be consistent with the empirical facts. The point here is not that rationalizations of the status quo are always false, but that people have a motive to search for such rationalizations regardless of the facts. Some members of disadvantaged groups defend and justify the system and its authorities even more strongly than do members of advantaged groups, presumably because they have a stronger need to reducc dissonance by justifying their suffering and their ongoing participation in the status quo. For example, extremely lowincome survey respondents in a national survey were more likely than middle- and higher-income people to endorse the beliefs that economic inequality is legitimate and necessary "to get people to work hard" and "as an incentive for individual effort." 43

\section{Which System Prevails in a Particular Conflict?}

Because every individual belongs to multiple social systems (e.g., family, work organization, society, religious order, nation-state) he or she may be motivated to justify several different states of affairs, and some justifications may conflict with others. Under circumstances of ideological conflict among competing social systems, the individual's (conscious or unconscious) "choice" of which system to justify will be determined by several variables. These variables may include dispositional factors (such as the strength of the individual's commitment to certain values and institutions, based on previous experience) and situational factors (such as the level of abstraction that is activated or primed by the circumstances and other environmental cues). In many cases, it may be difficult to distinguish the effects of system justification from behaviors that are caused by other factors. From a methodological point of view, researchers must therefore control or adjust for other potentially relevant variables to isolate the effects of system justification. Researchers typically accomplish this through one of two methods. First, they may use experimental methods, so that individuals are randomly assigned to experimental conditions and extraneous factors are distributed innocuously across the various conditions. Second, researchers can use statistical techniques such as multiple regression, whereby the effects of potentially confounding variables are estimated and "partialled" (or subtracted) out of the equation that is used to model behavior. Both of these methods have been used to assess predictions derived from SJT.

and minorities will conclude that the system is meritoeratic and fair at substantial cost to their own selfesteem). Jost et al., supra note 26.

43. Jost et al., supra note 17, at 23-24 (Study 3). 


\section{B. Empirical Manifestations of the System Justification Motive}

Dozens of studies using quite different methodologies provide empirical support for SJT. Some studies examine the structure and correlates of social and political attitudes as revealed by opinion surveys. Others use purely experimental methods to try to isolate the effects of system justification motives under more controlled conditions. As with scientific investigation in every field, no single experimental result can be dispositive. Because of the enormous complexity of human behavior and social interaction, theories in the behavioral sciences cannot be judged by how well they predict behavior in one or two experiments alone, but rather by how well they cohere with empirical results across a wide range of situations. Notably, a recent survey identifies twenty hypotheses generated by SJT that have thus far received significant empirical support. ${ }^{44}$

In this Part we describe evidence for some (but not all) of these twenty hypotheses, focusing on rationalization of the status quo, social stereotyping, and internalization of inequality. The methods used in these studies vary widely, from controlled experiments to statistical analyses of public opinion data. Although some of the effects observed in individual studies described here may be consistent with other theories, SJT is the only theory that accounts parsimoniously for all of these different effects. That is, SJT is useful because it can explain and integrate a wide range of apparently isolated phenomena.

\section{Rationalization of the Status Quo}

According to SJT, people rationalize not only their own actions and interests and those of fellow ingroup members, but also features of the social status quo that they neither chose nor originally desired. ${ }^{45}$ As the study of the 2000 election discussed in the lntroduction demonstrates, the preference for the status quo can extend even to the anticipated status quo. William J. McGuire and Claire McGuire suggested that people engage in both "sour grapes" and "sweet lemon" forms of rationalization by calibrating their desires so that they fit with beliefs about what is likely to occur. ${ }^{46}$ In other words, people come to value what is inevitable and to devalue

44. The evidence for these hypotheses is reviewed in Jost et al., supra note 16.

45. In this respect, SJT goes beyond cognitive dissonanee theory in maintaining that people justify not only their own decisions and behaviors, but also the decisions and behaviors of others (e.g., authorities) as well as outcomes that had no decision-maker at all. See Kay et al., supra note 5. The "status quo bias" (the tendency of decision-makers to prefer the status quo) and the "endowment effect" (the tendency of people to value more highly the same goods when they own them than when they do not) are well known to legal scholarship. See Russell Korobkin, The Endowment Effect and Legal Analysis, 97 Nw. U. L. REv. 1227, 1229 (2003). Between 1990 and 2003, the number of law review articles mentioning at least one of these phenomena grew from 2 to 373 . Id. SJT suggests that there is a motivational (as well as a cognitive) basis for the status quo bias and the endowment effect.

46. William J. McGuire \& C.V. McGuire, The Content, Structure and Operation of Thought Systems, in Advances in Social Cognition (R.S. Wyer, Jr. \& T.K. Srull eds., 1991). 
what is improbable, as in Aesop's fable. Several studies to date have demonstrated this basic process, which may underlie many system-justifying effects. $^{47}$

In order to cxplore the phenomenon in a more controlled setting, Kay and colleagues conducted a laboratory study concerning rationalizations of a decision made by University Trustees to either increase or decrease tuition rates. ${ }^{48}$ As the perceived likelihood of large tuition decreases rose, students were more likely to see the tuition decrease as desirable. As the perceived likelihood of a tuition increase rose, however, students were more likely to see the increase as desirable. Thus, more probable outcomes were seen as more desirable, regardless of whether they were initially defined as attractive or unattractive. ${ }^{49}$

Although they did not investigate anticipatory rationalization, Daniel Gilbert and his colleagues obtained similar evidence of post hoc rationalization of an undesirable outcome in a study of responses to a gubernatorial election. ${ }^{50}$ They contacted citizens who had voted in the 1994 Texas campaigu for governor involving Democrat Ann Richards and Republican George W. Bush just before the elections and approximately one month following them. On the first occasion, researchers asked voters to predict how happy they would be one month after the election if their candidate were to win or lose, as well as how they would evaluate Bush and Richards as the winning candidate. One month later researchers contacted voters again and asked them about their happiness and about their satisfaction with the winner, Bush. Gilbert and colleagues found that supporters of Ann Richards were significantly happier than they had expected to be, evaluated Bush more positively after the election than before, and felt better about their new governor than they had expected to feel. The authors conclude that "people fail to recognize that their negative affect will not merely subside but will be actively antagonized by powerful psychological mechanisms that are specifically dedicated to its amelioration ...."51

47. See, e.g., Lisa G. Aspinwall \& Shelley E. Taylor, Modeling Cognitive Adaptation: A Longitudinal Investigation of the Impact of Individual Differences and Coping on College Adjustment and Performance, 63 J. Personality \& Soc. Psychol. 989 (1992); Sonja Lyubomirsky \& Lee Ross, Changes in Attractiveness of Elected, Rejected, and Precluded Alternatives: A Comparison of Happy and Unhappy Individuals, 76 J. Personality \& Soc. Psychol. 988 (1999); William J. McGuire, $A$ Syllogistic Analysis of Cognitive Relationships, in ATtitude ORganization ANd Change, 65 (Milton J. Rosenberg et al. eds., 1960); Tom Pyszczynski, Cognitive Strategies for Coping with Uncertain Outcomes, 16 J. Res. Personality 386 (1982); Robert S. Wyer \& Lee Goldberg, A Probabilistic Analysis of the Relationships Among Beliefs and Attitudes, 77 PsycHOL. Rev. 100 (1970); see also JoN Elster, SOUR GraPES: Studies in The Subversion of Rationality (1983).

48. Kay et al., supra note 5 , at 1309 .

49. Id.

50. Daniel T. Gilbert et al., Immune Neglect: A Source of Durability Bias in Affective Forecasting, 75 J. Personality \& SoC. Psychol. 617, 624-26 (1998).

51. Id. at 619 . 
From a system justification perspective, these effects indicate not only people's inability to predict their own internal states, but also people's profound ability to rationalize the status quo. Prior to the elections, Ann Richard's supporters almost certainly did not possess the conscious goal of rationalizing a hypothetical victory for George Bush, and most likely had the opposite goal. However, once Bush's authority was firmly in place (that is, it became the status quo), system justification goals motivated Richard's supporters to justify and legitimize Bush's position as governor.

\section{Development and Endorsement of Social Stereotypes}

Perceptions of the social groups to which people belong mediate social interaction. ${ }^{52}$ Social psychologists commonly use the term stereotypes to refer to mental representations of social categories, which are thought to contain a mix of general propositions about the category (e.g., "lawyers are aggressive but articulate") and a collection of exemplars of the category (e.g., Perry Mason, Johnnie Cochran). ${ }^{53}$ Research has shown that stereotypes play an important role in system justification processes, particularly stereotypes concerning groups that are disadvantaged by the system. Two kinds of stereotypes about the disadvantaged, "victim-blaming" and "complementary" stereotypes, can serve system justification goals. ${ }^{54}$

First, as researchers have long noted, many negative stereotypes serve a "victim-blaming" function by highlighting the ways in which members of disadvantaged groups deserve their plight. ${ }^{55}$ For example, if the poor are seen as lazy, unmotivated, or irresponsible, then the social system that leaves them poor seems justified. ${ }^{56}$ When researchers gave University of Maryland students bogus information about the relative socioeconomic status of Maryland and Virginia alumni, the students viewed the more economically successful group as more intelligent, hard-working, and competent than the less successful group, and they came to see the less successful

52. See Linda Hamilton Krieger, The Content of Our Categories: A Cognitive Bias Approach to Discrimination and Equal Employment Opportunity, 47 STAN. L. REv. 1161 (1995).

53. See Ziva Kunda, Social Cognition: Making Sense of People 315 (1999). For a brief survey of the current theories of stereotyping, see Gary Blasi, Advocacy Against the Stereotype: Lessons from Cognitive Social Psyehology, 49 UCLA L. REv. 1241, 1254-66 (2002).

54. See Kay \& Jost, supra note 18; Kay et al., supra note 11, at 240 (system justification stereotypes include those that derogate society's "losers" while lionizing its "winners" and those in which "members of disadvantaged groups are ascribed compensating favorable charaeteristics and members of advantaged groups are ascribed unfavorable characteristics").

55. See, e.g., Gordon W. Allport, The Nature of Prejudice (1954); William Ryan, Blaming the Victim (1971); Melvin J. Lerner \& Carolyn H. Simmons, Observer's Reaction to the "Innocent Victim": Compassion or Rejection?, 4 J. Personality \& Soc. Psychol. 203 (1966).

56. For a comprehensive analysis of how this phenomenon has informed the welfare "reform" debate in the United States, see Martin Gilens, Why Americans Hate Welfare: Race, Media, and the Politics of Antipoverty Policy (1999) and Joel F. Handler \& Yeheskel Hasenfeld, The Moral Construction of Poverty: Welfare Reform in America (1991). 
group as more friendly, honest, and likeable than the less successful group. $^{57}$

The Maryland/Virginia study illustrates that in addition to victimblaming stereotypes, positive or "complementary" stereotypes serve system-justifying ends. Complementary stereotypes suggest that the disadvantaged have other compensating assets (such as, in the Maryland/Virginia study, honesty and likeability), or that the advantaged bear other burdens. For example, the happy-go-lucky, carefree vagrant and the bitter, lonely miser are complementary stereotypes common to many cultures. ${ }^{58}$ To the vast store of examples from history and current affairs, social psychologists have added some experimental evidence. Kay and Jost examined the impact of complementary stereotypes (e.g., "poor but happy" and "rich but unhappy") by exposing different groups of research participants to different vignettes describing in some detail the protagonist as (1) poor but happy, (2) rich but unhappy, (3) poor and unhappy, or (4) rich and happy. Researchers later asked the same participants to participate in what seemed to be an unrelated study, in which they completed a questionnaire regarding the fairness, legitimacy, and justifiability of the American social system. Kay and Jost found that merely exposing people to a story contaming a complementary stereotype led them to judge the American system as significantly more fair and legitimate. ${ }^{59}$

Kay, Jost, and Young demonstrated that victim-blaming stereotypes and complementary, victim-enhancing stereotypes are alternate routes to system justification, with the more likely route depending upon the perception of a causal link between trait and outcome. They made two related findings. First, derogating "losers" and lionizing "winners" on traits (such as intelligence) that are perceived as causally related to outcomes (such as wealth) serves to increase support for the status quo. Second, compensating "losers" and downgrading "winners" on traits that are perceived as causally unrelated (such as physical attractiveness) to those outcomes has the same effect of justifying the status quo. By simultaneously blaming the victims of misfortune on characteristics that are assumed to be causally linked to relevant social outcomes and compensating those same victims on causally unrelated dimensions, people sustain the two system-justifying beliefs that "people get what they deserve and deserve what they get" and that "no one

57. Jost \& Burgess, supra note 24, at 297-300.

58. A quick exercise on Google reveals 837 indexed documents in English referring to either the "happy vagrant" or the "carefree vagabond." See Google Home Page, http://www.google.com (last visited Mar. 11, 2006). The English term "miserable" derives from the same root as "miser" and shares origins with the Spanish misero (wretched) and Middle French (misere). Miser, Oxford English Dictionary, 2d Ed., http://www.oed.com (last visited Dec. 22, 2005).

59. Jost \& Kay, supra note 32, at 499. 
has it all." ${ }^{60}$ The experiments by Kay and colleagues suggest that these are not mutually exclusive but rather compatible, functionally equivalent routes to system justification. These experimental results also suggest parallels to common social stereotypes that members of disadvantaged groups have positive, compensating abilities in areas such as athletics or music.

\section{Internalization of Inequality}

When system justification motives conflict with ego justification, ego justification will at times give way, leading to self blame and a "depressed entitlement" effect. A number of studies have shown that women, as well as other individuals in low-paying jobs, come to feel that they deserve lower wages than men or other more highly paid individuals. ${ }^{61}$ For example, even in a feminist environment (Yale College in the 1990s), women who were asked to assign a value to their work "paid themselves" $18 \%$ less than men did for work that was indistinguishable in quality or content. ${ }^{62}$ Blanton and colleagues found that women felt they deserved less than men did for past work but not for future work. ${ }^{63}$ This evidence suggests that members of disadvantaged groups are motivated to justify the status quo, and even an anticipated status quo, but not an indeterminate future.

Dozens of studies have produced evidence of implicit outgroup favoritism among members of disadvantaged groups, which is another form of the internalization of inequality. ${ }^{64}$ Although members of advantaged groups (e.g., European Americans, heterosexuals) rarely exhibit implicit biases in favor of other, less advantaged groups, members of disadvantaged groups (including African Americans and homosexuals) commonly harbor preferences for members of other, more advantaged groups. The study discussed in the Introduction, in which Latino and Asian American students disproportionately chose White interaction partners, provided behavioral

60. These ideological beliefs were identified and discussed in different contexts. See LANE, supra note 40; LERNER, supra note 19.

61. See, e.g., Hart Blanton et al., Contexts of System Justification and System Evaluation: Exploring the Social Comparison Strategies of the (Not Yet) Contented Female Worker, 4 Group Processes \& 1NTergroup Rel. 126 (2001); Charlene M. Callahan-Levy \& Lawrence A. Messe, Sex Differences in the Allocation of Pay, 37 J. Personality \& Soc. Psychol. 433 (1979); Brenda Major et al., Overworked and Underpaid: On the Nature of Gender Differences in Personal Entitlement, 47 J. Personality \& Soc. Psychol. 1399 (1984); Brett W. Pelham \& John J. Hetts, Underworked and Overpaid: Elevated Entitlement in Men's Self-Pay, 37 J. EXPERIMENTAL. Soc. PsYchol. 93 (2001).

62. See John T. Jost, An Experimental Replication of the Depressed Entitlement Effect Among Women, Psych. WOMEN Q. 21387 (1997).

63. Blanton et al., supra note 61.

64. See, e.g., Jost, supra note 33; Jost et al., supra note 8; Jost et al., supra note 16. See also Leslie Ashburn-Nardo et al., Black Americans' Implicit Racial Associations and Their Implications for Intergroup Judgment, 21 Soc. CoGNITION 61 (2003); Eric Uhlmann et al., Subgroup Prejudice Based on Skin Color Among Hispanics in the United States and Latin America, 20 Soc. CoGNITION 198 (2002). 
evidence of outgroup favoritism. ${ }^{65}$ Many other studies use the lmplicit Association Test (lAT) ${ }^{66}$ to reveal implicit biases that perpetuate the existing hierarchy. This evidence indicates that people tend to accept and internalize (rather than reject and challenge) the social order.

Furthermore, research shows that disadvantaged group members who more strongly endorse system-justifying ideologies exhibit stronger implicit outgroup favoritism. Many different attitude measurement scales have been developed to reveal such aspects of such ideologies as "opposition to equality," "belief in a just world," "economic system justification," and political conservatism. A study by Ashburn-Nardo, Knowles, and Monteith, for example, found that African Americans who endorsed survey items measuring opposition to equality (a subscale of the "social dominance orientation" scale) were especially likely to exhibit a pro-White, anti-Black bias as measured by the 1AT. ${ }^{67}$ Similarly, other studies demonstrate that acceptance of system-justifying ideologies, as measured by individuals' scores on opinion scales that gauged agreement with the belief in a just world, economic system justification, and political conservatism, is associated with (1) increased ingroup favoritism among members of advantaged groups (such as Whites, Northerners, and heterosexuals), and (2) increased outgroup favoritism among members of disadvantaged groups (such as Blacks, Southerners, Latinos, and homosexuals) on both implicit and explicit measures. ${ }^{68}$

\section{Social and Psychological Moderators of System Justification}

To posit the existence of a motive is not to presume a specific result in every case. As with most psychological tendencies, there are both dispositional and situational sources of variability in the expression of system justification. Personality and environment are important moderators of the system justification response.

65. See Jost et al., supra note 8 .

66. The Implicit Association Test (IAT) measures the relative speed with which respondents can perform tasks that associate a category (e.g., Black or White) with a valence (positive or negative). The lAT is described in detail in the contribution Greenwald \& Krieger, supra note 10,952-55.

67. Ashburn-Nardo et al., supra note 64 .

68. See Jost \& Thompson, supra note 28; John T. Jost et al., Conflicts of Legitimation Among Self, Group and System: The Integrative Potential of System Justification Theory, in The PsycholoGY of Legitimacy: Emerging Perspectives on ldeology, Justice, and Intergroup Relations 363 (John T. Jost \& Brenda Major eds., 2001); Jost et al., supra note 16, at 902-05; John T. Jost et al., System-Justifying Functions of Complementary Regional and Ethnic Stereotypes: Cross-National Evidence, 18 SOC. JUST. RES. 305, 315-16 (2005); Shana Levin et al., Ethnic Identity, Legitimizing Ideologies, and Social Status: A Matter of Ideological Asymmetry, 19 POL. PsYCHOL. 373 (1998). 


\section{Dispositional Sources of Variability: Uncertainty and Threat Management}

With regard to dispositional factors, people who possess heightened needs to manage uncertainty and threat are especially likely to embrace conservative, system-justifying ideologies. Jost, Glaser, Kruglanski, and Sulloway demonstrated this in a meta-analysis that statistically aggregated results across a number of studies. The studies involved eighty-eight different research samples from twelve different countries, and over 22,000 individual participants or cases. The evidence clearly indicates that uncertainty avoidance, intolerance of ambiguity, needs for order, structure, and closure, perception of a dangerous world, and fear of death are positively associated with the endorsement of conservative, system-justifying ideologies. Cognitive complexity and openness to new experiences are negatively associated with the endorsement of these ideologies. ${ }^{69}$

Psychological needs to reduce uncertainty closely align with system justification because status quo arrangements are familiar and certain. Many people find the devil they know less threatening (and more legitimate) than the devil they do not know. Justifying the status quo satisfies several needs, including epistemic needs for consistency, coherence, and certainty, and existential needs to manage various forms of threat and distress and to find meaning in life. ${ }^{70}$

\section{Situational Sources of Variability: System Threat and Mortality Salience}

With regard to situational variables, the meta-analysis by Jost, Glaser, Kruglanski, and Sulloway also demonstrated that people find conservative, system-justifying beliefs more attractive under conditions of high system threat. ${ }^{71}$ Anecdotal observation and social scientific research both suggest that threats to the status quo, whether direct (as when the system is attacked) or indirect (as when its faults are exposed), provoke negative affect and motivate people to defend the social system. ${ }^{72}$ This defensive response, which can be automatic and unconscious, restores positive affect, but can have unanticipated and sometimes troubling consequences.

Several experimental studies demonstrate that people respond to threats to the social system by using stereotypes to justify inequality between groups, and by defending the status quo more vigorously. Jost,

69. Jost et al., supra note 22 , at 369 .

70. See Festinger, supra note 42; John T. Jost et al., The Ideological Animal: A Comparison of System Justification, Terror Management, and Just World Theories, in HANDBOOK OF EXPERIMENTAL Existential. Psychology (Jeff Greenberg et al. eds., 2004).

71. See Jost et al., supra note 22.

72. See, e.g., Richard M. Doty et al., Threat and Authoritarianism in the United States, 1978. 1987, 61 J. Personality \& Soc. Psychol. 629, 637 (1991); Stephen M. Sales, Threat as a Factor in Authoritarianism: An Analysis of Archival Data, 28 J. Personality \& Soc. Psychol. 44 (1973). 
Blount, Pfeffer, and Hunyady exposed Hungarian subjects to a written passage that criticized either the free market system (current status quo) or the socialist economic system (recent status quo), and exposed subjects in a control condition to a passage that contained no mention of either system. ${ }^{73}$ Researchers then solicited the subjects' attitudes toward capitalism and socialism. Results indicated that both of the system-threat passages led people who scored high in self-deception ${ }^{74}$ to express increased support for the capitalist status quo, including the acceptance of inequality. ${ }^{75}$

Threats to the social order can also increase people's desire for revenge against the perpetrators of those threats, apparently in an effort to defend and protect the social order. A series of experiments by Rucker, Polifroni, Tetlock, and Scott demonstrated that people become more punitive toward the perpetrator of a given crime when that crime threatens the social system. Researchers manipulated people's perceptions of the extent to which certain crimes (e.g., carjacking) were successfully prosecuted. They found that when they represented crimes as common but frequently unpunished (that is, highly threatening to the social order), people assigned more severe punishments to defendants accused of that crime. ${ }^{76}$ In a separate study, Kaiser, Vick, and Major showed that when people held stronger just-world beliefs prior to the terrorist attacks of 9/11, they experienced more emotional distress after the attacks and more strongly desired revenge two months later. ${ }^{77}$ Threats to the existing system, as long as they do not unseat the current regime and establish another one in its place, stimulate defense of the existing system and vengeance against those who threaten it.

Numerous experiments have demonstrated that reminding people of their own mortality increases their endorsement of system-justifying beliefs and stereotypes, as well as their attraction to conservative politicians and policies. $^{78}$ The $9 /$ I I terrorist attacks simultaneously evoked mortality salience and system threat, perhaps explaining why the attacks precipitated strong, bipartisan increases in patriotism, faith in American institutions,

73. Jost et al., supra note 26

74. Self-deception, which refers to the individual propensity to embrace self-serving beliefs and motivated illusions, was measured in terms of individuals' scores on a Hungarian translation of Paulhus' scale for gauging "self-deceptive enhancement." See D.L. Paulhus, Two-Component Models of Socially Desirable Responding, 46 J. Personality \& Soc. Psychol. 598, 599 (1984).

75. See Jost et al., supra note 26 , at 76-79.

76. Derek D. Rucker et al., On the Assignment of Punishment: The Impact of General-Societal Threat and the Moderating Role Of Severity, 30 Personality Soc. Psychol. Bull. 673, 677 (2004).

77. Cheryl R. Kaiser et al., A Prospective Investigation of the Relationship Between Just-World Beliefs and the Desire for Revenge After September II, 200I, 15 PsychOL. ScI. 503 (2004).

78. See, e.g., Florette Cohen et al., Fatal Attraction: The Effects of Mortality Salience on Evaluations of Charismatic, Task-Oriented, and Relationship-Oriented Leaders, 15 PsYCHOL. SCI. 846 (2004); Mark Landau et al., Deliver Us from Evil: The Effects of Mortality Salience and Reminders of 9/II on Support for President George W. Bush, 30 Personality Soc. Psychol. Bull. 1136 (2004); Jeff Schimel et al., Stereotypes and Terror Management: Evidence that Mortality Salience Enhances Stereotypic Thinking and Preferences, 77 J. Personality \& SOC. Psychol. 905 (1999). 
and support for the Bush administration and its policies. ${ }^{79}$ Consistent with the meta-analytic findings of Jost, Glaser, et al., ${ }^{80}$ Landau and colleagues experimentally primed subjects to think about the 9/11 attacks two years later, and found that they showed significantly more support for President Bush than did those who were not primed. ${ }^{81}$ Members of the control groups, who were primed to think about a negative event or about extreme pain, did not show a parallel increase in support for the President, indicating that system threat and mortality salience are especially important motivating factors for system justification. ${ }^{82}$ Time-series analyses by sociologist Robb Willer reveal that every time the Bush administration raised the terror-alert levels between 2001 and 2004, which increased both system-threat and mortality concerns, public approval ratings of President Bush increased, even on economic issues, a dimension unrelated to his handling of terrorism. $^{83}$

Research findings drawing on experimental, quasi-experimental, and correlational methods demonstrate that situational cues can produce significant increases in the degree of system justification, particularly when the system is threatened. When regime change seems inevitable, however, experiments by Kay, Jimenez, and Jost suggest that many people will begin to rationalize the new arrangements almost immediately. ${ }^{84}$

\section{Consequences of System Justification}

\section{The Palliative Function of System Justification and System-Justifying Ideologies}

In highly unequal social systems, both those who are advantaged and those who are disadvantaged by the system risk experiencing emotional distress. Advantaged and disadvantaged group members suffer different types of distress, and they may use different system-justifying processes to manage their distress.

The powerful may experience guilt over their advantaged position if they believe it is undeserved. For example, European Americans experience guilt and dissonance when confronted with evidence of fellow group members' prejudicial or discriminatory actions toward African

79. These public opinion trends following $9 / 11$ were documented by the Gallup Organization in Internet articles by Jeffrey M. Jones, Sept. 11 Effects, Though Largely Faded, Persist (Sept. 9, 2003), http://poll.gallup.com/content/default.aspx?Cl=9208 (account required for access) and Lydia Saad, Have Americans Changed? (Sept. 11, 2002), http://poll.gallup.com/content/default.aspx?Cl=6790 (account required for access).

80. See Jost et al., supra note 22.

81. Landau et al., supra note 78, at 1142-44 (2004).

82. Id.

83. Rob Willer, The Effects of Government-Issued Terror Warnings on Presidential Approval Ratings, 10 CURrent Res. IN SOC. PSYCHOL. 1, 10 (2004).

84. See Kay et al., supra note 5 , at 1311 . 
Americans. ${ }^{85}$ Similarly, men who are reminded of their gender privilege experience increased guilt and decreased well-being. ${ }^{86}$ To assuage their guilt, ease their consciences, and reduce dissonance arising from inequality in the system, people rationalize their own state of advantage, and derogate those who are disadvantaged. ${ }^{87}$

The powerless, meanwhile, may at times feel frustrated and angry about their position in society. In order to minimize irritation and resentment with barriers to individual and social mobility, they may lower their own aspirations and adapt to the status quo. System justification serves a palliative function, at least in the short run and at the level of conscious awareness. It operates as a coping mechanism for members of both advantaged and disadvantaged groups, reducing anxiety, uncertainty, and distress and promoting positive rather than negative affect. Survey research shows, for example, that poor people who blame themselves for their own poverty report feeling more positive emotion, less guilt, and greater satisfaction than poor people who blame the system. ${ }^{88}$

Research also shows that people who more strongly endorse a meritocratic ideology report higher satisfaction in their jobs, financial situations, and life in general. Jost, Pelham, Sheldon, and Sullivan examined the effects of demographic variables (race and socioeconomic status (SES)) and ideological beliefs concerning meritocracy and the legitimacy of economic inequality on satisfaction. Structural equation modeling revealed two effects. First, African Americans and people who were lower in SES were more likely than others to view socioeconomic differences as necessary and legitimate, apparently because they had stronger needs to reduce dissonance and restore positive affect. Second, endorsement of meritocratic ideology was positively related to satisfaction for all respondents. ${ }^{89}$ That is, the more people believed that hard work, ability, and motivation lead to success, the more they reported satisfaction with their own economic situation, regardless of whether they were rich or poor.

85. See, e.g., Janet K. Swim \& Deborah L. Miller, White Guilt: Its Antecedents and Consequences for Attitudes Toward Affirmative Action, 25 Personality Soc. Psychol. Bull, 500 (1999); see also Russell Spears et al., The (Il)legitimacy of Ingroup Bias: From Social Reality to Social Resistance, in The Psychology of Legitimacy: Emerging Perspectives on Ideology, Justice, AND INTERGROUP RELATIONS, supra note 68 , at 332.

86. See N.R. Branscombe, Thinking About One's Gender Group's Privileges or Disadvantages: Consequences for Well-Being in Women and Men, 37 BRIT. J. SOC. PSYCHOL. 167 (1998).

87. See Emmeline S. Chen \& Tom R. Tyler, Cloaking Power: Legitimizing Myths and the Psychology of the Advantaged, in The Use and Abuse of Power: Multiple Perspectives on the Causes of Corruption (Annette Y. Lee-Chai \& John A. Bargh eds., 2001); Jost \& Hunyady, supra note 22 .

88. James R. Kluegel \& Eliot R. Smith, Beliefs About Inequality: Americans' View of What Is AND What OUGHT TO BE 280-83 (1986).

89. Jost et al., supra note 17, at 27-29 (Study 5). 
Studies show that merely giving people an opportunity to endorse the legitimacy of the status quo leads participants in a hierarchical system to experience more positive affect and less negative affect, regardless of their own social position. ${ }^{90}$ While these palliative effects may improve subjective well-being for individuals (at least in the short term), individual acts of system justification result in continued inequality. Increased system justification (either in terms of ideological endorsement or the temporary activation of a "Horatio Alger" rags-to-riches mindset) alleviates people's negative emotional states, and thereby undermines support for the redistribution of resources and the desire to help the disadvantaged. ${ }^{91}$ In general, system-justifying ideologies operate like the "opiate of the masses" described by Marx and Engels, making people more content with their current situation and therefore less likely to rebel against the status quo.

System justification may have very different short- and long-term effects. Studies show that conflict among long-term goals is associated with poorer psychological well-being, including decreased life satisfaction and affective problems. ${ }^{92}$ Consistent with these findings, Jost and Thompson showed that opposition to equality is positively related to self-esteem and negatively related to depression and neuroticism for members of advantaged groups, but it is negatively related to self-esteem and positively related to depression and neuroticism for disadvantaged group members. ${ }^{93}$ Thus, engaging in system justification may have positive emotional consequences for members of disadvantaged groups in the short term, but deleterious consequences in the long term.

\section{Implications for Change and Adaptation to a New Regime}

When the status quo changes, or appears likely to change, individuals must adjust to it. Alternatives to the status quo may be unappealing when they seem improbable, but these alternatives will become more attractive as their probability of success increases. ${ }^{94}$ According to SJT, then, change almost always breeds resistance, but innovation can occur because people will eventually accept what they once viewed as untenable. Thus, when a

90. Cheryl J. Wakslak et al., System Justification and Emotional Distress: Palliative Effects of Ideology and Consequences for Redistributive Social Policies (Oct. 19, 2005) (unpublished manuscript, on file with authors).

91. Id.

92. See Robert A. Emmons \& Laura A. King, Conflict Among Personal Strivings: Immediate and Long-Term Implications for Psychological and Physical Well-Being, 54 J. Personality \& Soc. Psychol. 1040 (1988); Michaela Riediger \& Alexandra M. Freund, Inference and Facilitation Among Personal Goals: Differential Associations with Subjective Well-Being and Persistent Goal Pursuit, 30 Personality Soc. Psychol. Bull. 1511 (2004).

93. See Jost \& Thompson, supra note 28, at 229; see also Laurie T. O'Brien \& Brenda Major, System-Justifying Beliefs and Psychological Well-Being: The Roles of Group Status and Identity, 3I Personality Soc. Psychol. Bull. 1718 (2005).

94. See Kay et al., supra note 5. 
new status quo is clearly established (e.g., by a court ruling, a new law, an election, a coup d'etat, or military victory), people perceive the emerging social arrangements in increasingly favorable terms and begin to justify and rationalize the new regime. Defending the old system no longer has psychological benefits, and so people will cease to justify it.

Researchers observed such a process after Brown v. Board of Education. ${ }^{95}$ Herbert Kelman described a 1954 study concerning African American students' attitudes toward maintaining some private all-Black colleges in the face of the Supreme Court's impending decision on racial desegregation in education. ${ }^{96}$ After hearing a persuasive message advocating the voluntary maintenance of some all-Black colleges, students expressed their attitudes three days before the decision and again on the day of the decision. Regardless of the source and degree of the communicator's power, students opposed maintaining all-Black colleges far more strongly after the Brown decision than before. That is, when segregation was part of the status quo, African Americans professed stronger support for voluntary segregation. When integration became the status quo three days later, the same group of students became more enthusiastic integrationists.

According to SJT, then, initial resistance to change is greater than other theories would predict, yet adaptation to imminent change is easier. As soon as the new system is seen as inevitable, people begin to rationalize its distinctive features, both consciously and unconsciously. This phenomenon seems to have occurred in Eastern Europe in the late 1980s and early 1990s, as many people rapidly transferred their psychological allegiance from one system (state socialism) to another (market capitalism) ${ }^{97}$ SJT predicts that social change will either come not at all or all at once, the way that catastrophic change occurs in dynamic systems and in "tipping point" phenomena. ${ }^{98}$

\section{E. Summing Up the Science}

The preceding summary of the scientific evidence for SJT may not convince every reader. Some experimental results or survey findings consistent with SJT may be consistent with other hypotheses, explanations, or theories. Because of the enormous complexity of human behavior and social interaction, theories in the behavioral sciences cannot be judged by how they fare in predicting behavior in one or two experiments, but by how

95. 349 U.S. 294 (1955).

96. See Herbert C. Kelman, Reflections on Social and Psychological Processes of Legitimization and Delegitimization, in PSYCHOLOGY OF LegitimaCY, supra note 68, at 54, 60.

97. See Jost et al., supra note 26.

98. For a popular account, see Malcolm Gladwell, The Tipping Point: How Little Things Can Make a Big Difference (2000) 
well they cohere with empirical results across a wide range of situations. ${ }^{99}$ To date, research has provided empirical support for twenty hypotheses derived from a system justification framework. ${ }^{100}$ One thing is reasonably certain, however: our common, lay understandings of the motivations of individuals, especially their heavy reliance on rational self-interest, are to some degree simply wrong. Behavioral realists believe that both lawyers and legal academics should take notice.

\section{II}

\section{AdVOCACY RESPONSES to SYSTEM JUSTIFICATION}

Lawyers and other advocates should take account of SJT because all advocacy rests on assumptions and predictions about motives and motivated behavior. Most people, including advocates, interact with people on the basis of a "folk psychology,"101 just as they interact with the physical world on the basis of a "folk physics." Much of the time, our unscientific, implicit theories work fine and the predictions we make are accurate enough. But sometimes we are simply wrong. For example, many of us believe, with Aristotle, that if we tie a weight to the end of a string, swing it around our heads, and then let go, the weight will follow a curved path (as viewed from above). ${ }^{102}$ Similarly, our folk social psychology leads us to attribute individual behavior to individual dispositions rather than situational characteristics. Scientists have labeled this phenomenon the fundamental attribution error, ${ }^{103}$ although more recent evidence suggests that it may be "fundamental" only for people in Western cultures. ${ }^{104}$

99. Within the philosophy of science, this perspective is known as coherentism and the criterion of a good theory is its explanatory coherence. See generally, Paul Thagard, Explanatory Coherence, 12 Behav. \& BralN SC1. 435 (1989).

100. Jost et al., supra note 16.

101. The term "folk psychology" refers to the "implicit theory that growing up in society has provided us." Alexander Rosenberg, Philosophy of Soclal Science 19 (2d ed. 1995). Other terms for the concept are "naïve psychology" and "intuitive psychology." See, e.g., Lee Ross, The Intuitive Psychologist and His Shortcomings: Distortions in the Attribution Process, 10 Advances iN EXPERIMENTAL Soc. Psychol. 173 (1977).

102. The weight will in fact follow a straight line, in the direction determined by the forces operating on the weight at the moment of its release. See generally Andrea DiSessa, Unlearning Aristotelian Physics: A Study of Knowledge-Based Learning, 6 Cognitive ScI. 37 (1982) (analyzing the rclation of modern "folk physics" to Aristotle); see also Kurt Lewin, The Conflict Between Aristotelian and Galilean Modes of Thought in Contemporary Psychology, 5 GEN. PsYchoL. 141 (1931).

103. Ross, supra note 101 , at 184 ; see also SuSAN T. Fiske \& Shelley E. TAYlor, Social COGNITION 67-72 (2d ed. 1991).

104. See, e.g., Michael W. Morris \& Kaiping Peng, Culture and Cause: American and Chinese Attributions for Social and Physical Events, 67 J. Personality \& Soc. Psychol., 949, 967-68 (1994); see also Richard E. Nisbett, The Geography of Thought: How Asians and Westerners Think Differently . . A AND Why (2003); G.J.O. Fletcher \& C. Ward, Attribution Theory and Processes: $A$ Cross-Cultural Perspective, in The Cross Cultural Challenge to Social Psychology 230 (Michael Harris Bond ed., 1988). 
Both folk and scientific psychologies of motivation acknowledge the importance of self-interest (or ego justification) and of social group identification (or group justification). In many circumstances, these theories may suffice. But in circumstances in which social systems are relevant and significant, ignoring system justification motives may lead to serious errors in predicting attitudes and behavior, both in developing legal regimes intended to constrain behavior, and in shaping arguments and policy interventions.

In Part III we discuss some implications of SJT for law and regulation. In this Part we explore how SJT can inform lawyering and advocacy. Practicing lawyers and other advocates know quite a lot about how to shape arguments that attend to ego justification, group justification, and other motives, although they have paid insufficient attention to the role of implicit attitudes and motives in shaping behavior. ${ }^{105}$ However, like lawmakers, judges, and scholars, they have paid virtually no attention to the influence of the system justification motive. Because lawyers are unaware of any adequately grounded theoretical account of system justification, they simply label and decry the relevant phenomena, such as the depressed sense of entitlement among the disadvantaged, and the apparently irrational support of policies that are contrary to self and group interest. ${ }^{106}$ In this Part, we consider advocacy strategies that could respond to the effects of system-justifying motives in particular circumstances.

\section{A. Analyzing a Hypothetical Case}

For purposes of illustrating our general theoretical framework, we rely on the following hypothetical litigation.

\section{l. The Case: Pat v. Aerocomposites}

Pat is a machinist at Aerocomposites, Incorporated during the day and takes engineering classes at night. Pat is a hard worker who has, until recently, exceeded production quotas and had a very low error rate. The low error rate is important because Aerocomposites produces parts for helicopters, primarily transport helicopters used by the U.S. Army. The wars in Afghanistan and Iraq have led to expanded operations at Aerocomposites.

Aerocomposites itself resembles a military operation in some ways. The workplace has a strict hierarchy from top management all the way to the shop floor. Occasionally an engineer will stop by to talk to Pat's foreman in the rotor blade department, but it would seem very unusual if an engineer actually talked to Pat. The plant is unionized. Pat belongs to the machinists' union but is not active in union affairs. The union is itself fairly

105. See Blasi, supra note 53, at 1254-66.

106. See, e.g., Dennis Fox, Psycholegal Scholarship's Contribution to False Consciousness About Injustice, 23 Law \& Hum. BeHav. 9 (1999) (discussing "false consciousness" in legal contexts). 
hierarchical and is run in top-down fashion by the president of the union local. The general political culture of both the community and the plant is both patriotic and conservative, although by no means uniformly so. Pat, for instance, opposes the Iraq War, and some of the other employees know that.

Pat's interest in engineering and experimenting, which goes well beyond normal job responsibilities, led to finding a slight flaw in the way rotor blades were being assembled. Under extreme temperatures, not unusual in Iraq in summer, the blades might deteriorate much more rapidly than had been expected. The flaw would probably not lead to catastrophic failures because the failure would become apparent over time, but the flaw would require earlier-than-expected blade replacement. The time Pat spent on these investigations meant less time spent on machining work on the shop floor, and to more errors, all of which were identified and corrected before the final assembly process. Pat brought the experimental findings to the department foreman and the engineering department, but both were dismissive, telling Pat to save engineering investigations for night school. The foreman also complained that Pat's productivity and error rate had suffered while Pat "played engineer." Pat got upset and exchanged some angry words with both the foreman and the engineer, but went back to work.

Shortly thereafter, and a week before a Defense Department audit team was scheduled to visit the Aerocomposites plant, Pat was fired for insubordination and poor performance. After Pat's unsuccessful appeal to the union for help, Pat sued Aerocomposites for wrongful discharge and sued the union for breach of the duty of fair representation.

How might Pat's lawyer take advantage of scientific knowledge about system justification motives in crafting a coherent, legally useful story of what has happened? How might these stories play to jurors of varying races, genders, and system justification orientation? How might they intersect with political ideology? Who would be the ideal juror? SJT provides some ways of thinking systematically about these questions, and suggests consideration of factors that might otherwise escape the attention of an experienced litigator or jury consultant.

\section{Assessing System Justification Motives}

Advocacy, like all problem-solving approaches, begins with an assessment of the current situation. Advocacy strategies depend upon the advocate's theory, implicit or explicit, of the values, motives, and interests of the people the advocate seeks to influence. The theory includes beliefs or assumptions about the targets of advocacy: their state of knowledge, their attitudes, and their motives. Other theoretical assumptions allow the advocate to predict how given advocacy targets will respond to a specific argument or presentation. Advocates can acquire information about an 
audience's state of mind through various means, some of which are more rigorous than others. When the targets are jurors, lawyers rely on investigation, voir dire, and other intuitive or ostensibly scientific means. ${ }^{107}$ For audiences outside the courtroom, advocates rely on experience as well as more systematic approaches: focus groups, sample surveys, and even controlled experiments. ${ }^{108}$ No practicing lawyer or advocate would be surprised to learn that he or she ought to take the self-interest or perceived group identity of an audience into account. But many would be surprised to learn that they ought also to consider system justification motives. Whether picking a jury or designing a political campaign strategy, advocates can draw on the survey instrumentation developed by system justification researchers to assess the system-justifying dispositions of potential advocacy targets. Although lawyers generally cannot ask jurors directly about their political orientation, they often ask about current events or public policy inclinations. They could also ask more general questions developed by personality and social psychologists to gauge levels of ideological support for existing authorities and institutions. ${ }^{109}$

As we have seen, system justification motives interact with other motives to affect attitudes and behavior. For example, the hypothetical case described in Pat v. Aerocomposites does not ascribe a race or gender to Pat. However, there can be little doubt that race and gender will matter to Pat's lawyers in their selection of the jury and argument in court, whether race connects to the evidence in the case or not. Conventional wisdom (and group justification and social identity theories) instruct lawyers to choose jurors of Pat's own gender and race:

The simplest rule regarding the relationship between juror and the defendant is what social psychologists call the similarity principle. It is also the principle most often used by attorneys to govern their own voir dire when no consultant has been retained. In most aspects of life, people prefer others who are similar to themselves. ${ }^{110}$

107. The literature on jury seleetion is voluminous. See, e.g., JefFrey T. Frederick, The Psychology of the American Jury (1987); V. Hale Starr \& Mark McCormick, Jury Selection: An attorney's Guide to Jury Law and Methods (1985); Richard C. Waites, Courtroom Psychology and Trial Advocacy (2003).

108. Experiments can, for example, present subjects and controls with bogus "news stories" that are identical except for the intervention in question, and then measure the relative effects on attitudes. See, e.g., Shanto lyengar, Experimental Designs for Political Communication Research: From Shopping Malls to the Internet (June 25-26, 2002), http://pcl.stanford.edu/common/docs/research/ iyengar/2002/expdes2002.pdf.

109. See, e.g., Sidanius \& PRATto, supra note 28; Altemeyer, supra note 27; Jost \& Kay, supra note 32; Jost \& Thompson, supra note 28; Jost et al., supra note 26; Kay \& Jost supra note 18; Herbert L. Mirels \& James B. Garrett, The Protestant Ethic as a Personality Variable, 36 J. Consulting \& Clinical Psychol. 40 (1971); Rubin \& Peplau, supra note 24.

110. Neil J. Kressel \& Dorit F. Kressel, Stack and Sway: The New Science of Jury Consulting 114 (2002) (emphasis in original, footnote omitted). Existing literature and evidence on 
Lawyers attentive to the implications of SJT and the studies by Jost, Pelham, and Carvallo would conduct a considerably more nuanced analysis in picking a jury. They would ask questions at voir dire to illuminate prospective juror dispositions toward system justification. And they would note that members of low status groups (especially those who are high system justifiers) may show outgroup preferences. ${ }^{11}$

In addition, lawyers would want to know something about prospective jurors' life circumstances and experiences that might cause them to have dispositions toward particular systems implicated in the case. Pat $v$. Aerocomposites involves several such systems: the workplace and its structure of hierarchical relations between managers and employees; the union and its pattern of relations among union representatives and members, which can also be quite hierarchical; the system of professions and the differential valuing of high-status jobs (engineers) and low-status jobs (machinists); and, perhaps most significantly, the national system, including attitudes toward the current government, the war, and the military and national defense. If Pat is a woman, SJT suggests that, contrary to conventional wisdom, an upper-middle-class male juror may be more favorably disposed toward Pat than a high system-justifying, working class woman, particularly if the evidence in the case will likely focus on gender and workplace-deference issues. To fully test this hypothesis, researchers would need to employ empirical methods, perhaps assessing the attitudes of a mock jury. But even without more specific testing, lawyers should consider the possible effects of system justification motives in selecting a jury, and in deciding what evidence, witnesses, and arguments to present.

\section{Advocacy Strategies That Take System Justification Motives into Account}

In many settings, of course, advocates must take their audiences as they find them. Even so, equipped with a more complete and accurate theory of motivation and the role of motivation in hierarchical social

jury selection is, of course, extensive, ranging from the folk psychology and the conventional wisdom of practitioners, to academic studies using mock jury and other methods, to a very extensive industry of jury consultants. Often quoted advice by F. Lee Bailey and Henry Rothblatt, presumably based on somewhat limited empirical evidence, suggests that defense lawyers prefer "heavy, roundfaced, joviallooking" jurors to "the slight, undenweight and delicate type." F. LeE BAILEY \& HeNRY B. Rothblatt, Fundamentals of Criminal Advocacy 284-85 (1974); see also Frederick, supra note 107 , at 44 . For an entertaining self-reflection by a somewhat more thoughtful trial lawyer, see Robert $F$. Hanley, Getting to Know You, 40 AM. U. L. REv. 865 (1991). The empirical support for more scientific approaches, while mixed, is somewhat more extensive. KRESSEL \& KRESSEL, supra note 110, at 110-44 (reviewing studies); see also Solomon M. Fulero \& Steven D. Penrod, The Myths and Realities of Attorney Jury Selection Folklore and Scientific Jury Selection: What Works?, 17 OHIO N.U. L. Rev. 229 (1990).

111. See, e.g., Ashbum-Nardo et al., supra note 64; Jost et al., supra note 16; Jost et al., supra note 8. 
situations, lawyers and other advocates can make a number of tactical moves that take account of the insights of SJT. Advocates can deploy two somewhat different approaches, either in series or in tandem: altering the relative salience of systems and system justification, as compared to individual or group motives, and reframing the situation to call attention to one of several potentially salient systems. The first strategy relies on the fact that for any individual ego, group, and system justifying motives interact. Advocacy interventions can potentially raise or lower their relative salience. The second strategy assumes that every person is embedded in multiple and overlapping social systems. The same person can be a member of a family, a workplace hierarchy, a profession, and a social order marked by racial or gender hierarchies, and so on. Defending one system may come at the expense of another. Each individual must find ways of reducing dissonance resulting from potentially conflicting system justification motives as they inove from one situation to the next. SJT suggests that advocates should craft strategies that respond to the psychological need to reduce dissonance among competing system justification motives, as well as dissonance among ego, group, and system justifying motives. Advocates can do this by altering the ways in which the targets of advocacy frame the issues before them. Because these strategies rely primarily on processes commonly associated with "framing," we provide a short explanation of the concept, drawing again on psychological science.

\section{a. The Psychological Processes of Frame Shifting}

The terms frame and framing have come to mean slightly different things in several different disciplines, ${ }^{112}$ each of which has penetrated law and legal scholarship to a different degree. The "framing effect" first identified by Kahneman and Tversky, ${ }^{113}$ i.e., the tendency for people to prefer one presentation of a risky choice to another presentation of the same

112. Most scholarship in sociology and anthropology traces back to Erving Goffman, who defined frames as "schemata of interpretation" that enable individuals "to locate, perceive, identify, and label" aspects of the social world. ERving Goffman, Frame Analysis: An Essay on the Organization OF EXPERIENCE 21 (1974). Sociologists of social movements describe "framing" as the active process through which movement proponents are "actively engaged in the production and maintenance of meaning for constituents, antagonists, and bystanders or observers.” Robert D. Benford \& David A. Snow, Framing Processes and Social Movements: An Overview and Assessment, 26 ANN. REv. Soc. 611,613 (2000). Political psychologists and students of communications use the term in slightly different ways, but "agree that frames give meaning to key features of some topic or problem." Richard R. Lau \& Mark Schlesinger, Policy Frames, Metaphorical Reasoning, and Support for Public Policies, 26 Pol. Psychol. 77, 80 (2005). The concept is also put to important uses in linguistics and discourse analysis, see Framing in Discourse (Deborah Tannen cd., 1993), and cognitive science in which the seminal work is Marvin Minsky, A Framework for Representing Knowledge, in THE PsYchologY of COMPUTER Vision 211 (Patrick Henry Winston ed., 1975), available at http://web.media.mit.edu/ minsky/papers/Frames/frames.html.

113. See Amos Tversky \& Daniel Kahneman, The Framing of Decisions and the Psychology of Choice, 211 Scl. 453 (1981). 
choice, is perhaps the psychological effect best known to legal scholarship. ${ }^{114}$ And framing, as a more general concept referring to a tacit interpretation, is certainly not new to practitioners or scholars. ${ }^{115}$ The same event, such as the death of a child in an apartment fire, can be "framed" as a result of parental neglect, a greedy slumlord, or a deficient housing inspection program. ${ }^{16}$ Each frame implicates a different system: the family system, landlord/tenant relations, or the local government. Framing has consequences. Although all of these causal explanations might be true, most people gravitate toward only one of them. As one popular account put it, "[e]very frame defines the issue, explains who is responsible, and suggests potential solutions."117

Psychology can also help advocates understand how to alter the relative salience and framing of systems. To begin, we can note that priming, the simple act of exposing people to words or images associated with one system as opposed to another, will increase the salience of that system ${ }^{118}$ Thus, if advocates frequently use words and concepts associated with the preferred system, even indirectly or subliminally, they will make the activation of that system frame more likely. ${ }^{119}$ Pat's lawyers in our example would thus do well to mention words associated with the military, defense, safety, and patriotism. Even the promment traditional display of the American flag in the courtroom will likely have an effect on jurors, priming the "national system." 120

More complex mental processes can also affect the framing of systems. Specific analogies, metaphors, and scripts or "stock stories" often

114. See, e.g., Edward J. McCaffery et al., Framing the Jury: Cognitive Perspectives on Pain and Suffering Awards, 81 VA. L. REv. 1341 (1995).

115. Indeed, there are businesses focused precisely on helping advocates craft suitable frames. See the website of the FrameWorks Institute both for a good example as well as many useful references on the general subject of framing. FrameWorks Institute, http://www.frameworksinstitute.org (last visited Aug. 15, 2005).

116. See Charlotte Ryan, Prime Time Activism 55-56 (1991) (providing an example of how a hypothetical "Rats Bite Infant" story can be "framed" in many different ways).

117. Id. at 59 chart 3-2.

118. See Melissa J. Ferguson \& Ran R. Hassin, Automatic Ideology: Implicit Effects of American Nationalism on Attitudes, Judgment and Behavior (2006) (unpublished manuscript, on file with authors); see also Michael Billig, Banal Nationalism (1995).

I 19. What appears to matter is whether a mental construct is activated, not how this takes place. As one recent review put it,

99 out of 100 times the brain does not care at all whether something is primed subliminally or supraliminally. "We" (i.e., humans) do, as shown by the strong reactions evoke by the possibility of effects of subliminally presented stimuli on behavior, but our brains do not... In sum, it is the activation of a mental representation that is crucial for launching other psychological processes. The way this representation was activated (subliminal versus supraliminal) is not important.

Ap Dijksterhuis et al., The Power of the Subliminal: On Subliminal Persuasion and Other Potential Applications, in The New Unconscious 77, 86 (Ran R. Hassin et al. eds., 2005).

I20. See Ferguson \& Hassin, supra note I18; see also BILLIG, supra note 118. 
convey frames. ${ }^{121}$ Particularly important are analogies or metaphors that convey not only associations with content (e.g., the flag and "nation") but also internal structural relationships among their elements (e.g., the President as "father" of the country). ${ }^{122}$ Analogies that maintain the basic structure of relationships among the elements are most easily retrieved and applied. ${ }^{123}$ Thus, we find it easier to analogize from one hierarchical system to another, given that there are corresponding roles for leaders and followers. ${ }^{124}$ Metaphors that map from one system level to another are quite common: a family (of nations), (it takes) a village, ${ }^{125}$ a (salvation) army, a war on (poverty, drugs, terror). These frames are powerful both because they bring many implicit associations and because they activate thoughts about systems that are themselves the subject of system-justifying motives.

\section{b. Framing Strategies for Lawyers.}

Utilizing what we know about framing processes, advocates can develop interventions aimed in a particular setting at altering the relative importance of ego, group, or system justification motives. For example, when system-justifying motives undermine an advocate's goals, the advocate can elevate individual or group concerns to reduce the net effect of system justification motives. Lawyers cannot, of course, appeal to jurors' literal selfinterest in arguments, but they can, and commonly do, appeal to jurors' social identification. Furthermore, advocates should assume that the ego and group justification motives of individual jurors will affect the dynamics of jury deliberations. Efforts to activate ego or group justification motives are common both in trial settings (e.g., emphasizing racial identity in a jury trial) and in other settings (e.g., highlighting gender disparities in a public policy campaign). Although courts and commentators may disfavor

121. See, e.g., Gerald P. López, Lay Lawyering, 32 UCLA L. Rev. 1 (1985); Albert J. Moore, Trial by Schema: Cognitive Filters in the Courtroom, 37 UCLA L. REV. 273 (1989).

122. The cognitive linguist George Lakoff emphasizes the power of metaphors, particularly metaphors of family archetypes ("strict father" or "nurturant parent") to shape how people react to social and political issues. See George Lakoff, Moral Politics: How Liberals and Conservatives THINK ( $2 \mathrm{~d}$ ed. 2002). For a contemporary look at the spread of Lakoff's ideas to public discourse, see Matt Bai, The Framing Wars, N.Y. TIMES, July 17, 2005, $\S 6$, at 38 .

123. The seminal article on the importance of "structure-mapping" or relational mapping in analogical reasoning is Diedre Gentner, Structure-Mapping: A Theoretical Framework for Analogy, 7 COGNITIVE SCI. 155 (1983). More recent work has located the mapping of structural features within a broader context of pragmatic intent and semantic association. For an accessible overview, see KeITH J. Holyoak \& Paul Thagard, Mental Leaps: Analogy in Creative Thought 101-37 (1995). See also Diedre Gentner \& Arthur B. Markman, Structure Mapping in Analogy and Similarity, 52 AM. PsYCHOL. 45 (1997).

124. Barbara A. Spellman \& Keith Holyoak, If Saddam is Hitler then who is George Bush? Analogical Mapping Between Systems of Social Roles, 62 J. Personality \& Soc. Psychol. 913 (1992).

125. Notably, Hillary Rodham Clinton, It Takes a Village: And Other Lessons ChIldDen Teach Us (1996), is now matched by Rick Santorum, It Takes a Family: Conservatism and the Common Good (2005). 
explicit efforts to arouse group justification motives, group-based stereotypes and bias, whether implicit or explicit, are always at work in the courtroom. ${ }^{126}$

Returning to Pat v. Aerocomposites, Pat's lawyers will obviously want to consider juror motives other than, and especially in opposition to, system justification. Pat's gender and race will be apparent to jurors. How much attention jurors pay to these group characteristics will depend on the stories advanced by the parties, as well as jurors' more subtle considerations of Pat's appearance, dress, language, accent, and social class. Blasi has written extensively on how lawyers can respond to the potential of implicit bias. ${ }^{127}$ Trial lawyers have numerous means of implicitly appealing to group interests in order to raise or lower the relative salience of group identity.

When the system justification motives of a target audience align with the advocate's goals, advocacy can also amplify their effect. Demagogues of all stripes have demonstrated what the "system threat" experiments reveal: efforts to highlight system threats will amplify system justification motives. Of course, perceived system threat is also affected by framing. Did Pat's actions threaten Aerocomposites, or did Aerocomposites threaten the country?

Relying on the fact that in every situation, people occupy multiple roles and are embedded in multiple, overlapping social systems, lawyers can also use framing techniques to emphasize one system and downplay another. Thus in Pat v. Aerocomposites, attorneys for Aerocomposites may frame the firm as a family, now betrayed by the litigious Pat. The union can make a similar case; after all, many union members still refer to each other as "brother" and "sister." Pat's lawyers will advance "Citizen Pat," whose loyalty is to the national family rather than to the union or the corporation. Notably, in these different frames, the values of deference and loyalty are the same; only the system that serves as a reference point has changed.

\section{c. Reframing Systems, Social Issues, and Social Change}

Although framing processes enter into every trial, system framing can be especially critical to social and political advocacy. We consider two examples from quite different settings that illustrate the processes and the potential: debates about affirmative action and the campaign to repeal the federal estate tax.

126. See, e.g., John M. Conley et al., The Racial Ecology of the Courtroom: An Experimental Study of Juror Response to the Race of Criminal Defendants, 2000 WIS. L. REV. 1185 (2000).

127. Blasi, supra note 53, at 1241. 


\section{Framing Affirmative Action}

The framing of "affirmative action" has a dramatic impact on attitudes. ${ }^{128}$ Psychological frames, like picture frames, limit what the observer considers. The current, predominant frame for affirmative action extends only to the current processes by which applicants for scarce positions are selected. However, this frame ignores history, the lingering effects of past discrimination, and the evidence of current and unintended discrimination. Such a frame amplifies the ego justification and group justification motives of White people and men by highlighting the potential zero-sum consequences of affirmative action. Finally, in this frame, affirmative action collides with the system-justifying ideologies of meritocracy and faith in the legitimacy of the free market, both of which bolster the broader socioeconomic system. ${ }^{129}$

An alternative framing of affirmative action encompasses history, including the effects of past discrimination ${ }^{130}$ and past affirmative action for Whites. ${ }^{131}$ This frame also acknowledges the consequences of affirmative action not merely for individuals in zero-sum contests, but also for institutions and systems to which system justification motives are directed.

The United States military's amicus brief to the Supreme Court in Grutter v. Bollinger persuasively used this frame, arguing that "a highly qualified, racially diverse officer corps educated and trained to command our nation's racially diverse enlisted ranks is essential to the military's ability to fulfill its principal mission to provide national security." 132 This framing of affirmative action directly appealed to system justification motives. Moreover, the military's brief reduced the pull of ego and group

128. Affirmative action to reduce racial or gender inequality is the subject of a behavioral realist reanalysis by our colleagues Kang and Banaji in this Symposium issue. Jerry Kang \& Mahzarin $\mathbf{R}$. Banaji, Fair Measures: A Behavioral Realist Revision of "Affirmative Action" 94 CALIF. L. REV 1063 (2006).

129. It is worth noting that a substantial minority (28\%) of Blacks opposed federal efforts "to improve the social and economic position of Blacks and other minority groups." Gallup Organization, Public Split on Federal Role in Affirmative Action (May 6, 2003), http://brain.gallup.com/content/ default.aspx?ci=8347.

130. For evidence on the persisting effects of inequality of intergenerational transfers of wealth, see Melvin L. Oliver \& Thomas M. Shapiro, Black Wealth, White Wealth: A New Perspective on Racial Inequality 152-56 (1997), and Seymour Spilerman, Wealth and Stratification Processes, 26 ANN. Rev. Soc. 497, 510-16 (2000).

131. See Ira Katznelson, When Affirmative Action Was White: An Untold History of RaCial INEQuality IN TWENTIETH-CENTURY America (2005) (recounting the history of affirmative government programs limited to Whites only).

132. Consolidated Brief of Lt. Gen. Julius W. Becton et al. as Amici Curiae Supporting Respondents at 5, Grutter v. Bollinger, 539 U.S. 306 (2003) (No. 02-24l, 02-516), http://www.umich.edu/ urel/admissions/legal/gru_amicus-ussc/um/MilitaryL-both.pdf. Notably, the military tops the list of institutions in which Americans say they have "a great deal" or "quite a lot" of confidence. See Lydia Saad, Military Still Tops in Public Confidence, The Gallup Poll, Jun. 7, 2006, (on file with authors) (the military has either "a great deal" or "quite a lot" of confidence of $73 \%$ of Americans, compared, e.g., to the U.S. Supreme Court (40\%) or HMO's (15\%)). 
justification motives, given that far fewer individuals or groups are likely to compete for spots in the military than in the academic admissions contexts in which the litigation arose.

Of course, the possible reframings of affirmative action extend beyond those that alter the relative influence of system justification motives. Kang and Banaji argue in this volume for a new temporal framing predicated on the contemporary evidence of pervasive implicit bias. This framing views 'properly designed 'affirmative action' programs as responses to discrimination in the here and now." 133 The affirmative programs Kang and Banaji propose are "properly designed" to ameliorate or reduce implicit biases rather than to counteract the effects of past discrimination through set asides or preferences. ${ }^{134}$ Thus, this reframing may effectively turn the classic anti-affirmative action "unwarranted preferences" frame upside down, leaving opponents to explicitly justify existing implicit preferences that disadvantage women and people of color.

\section{Repeal of the Federal Estate Tax}

The remarkably successful campaign to eliminate the federal estate tax provides another example of the power of system-framing in policy advocacy. Michael J. Graetz and lan Shapiro devote a fascinating book to answering an important question: "How did so many people who were unaffected by the estate tax-the most progressive part of the tax law-and who might ultimately see their own taxes increased to replace the revenues lost if the estate tax disappeared, come to oppose it?"135 Their answer, which draws on historical analyses of policy debates and organizational struggles, is complicated, but SJT offers a social-psychological account that is compatible with their institutional account.

Federal estate taxes involve two systems in which everyone is a part: a family and a nation. Repeal advocates, led by the Family Business Estate Tax Coalition, ${ }^{136}$ successfully framed the issue as one of family rather than country. Moreover, by renaming the estate tax a "death tax," repeal advocates took advantage of the motivational effects of mortality salience and system threat. ${ }^{137}$ Repeal opponents essentially conceded the ground within the family frame. To our knowledge, no one has yet suggested naming the repeal legislation the "Paris Hilton Silver Spoon Act."138

Widespread public ignorance of the facts allowed conservatives to successfully emphasize the family frame in a way that implicated

\footnotetext{
133. Kang \& Banaji, supra note 128 , at 1066.

134. Id. at 1095-1102.

135. Michael J. Graetz \& lan Shapiro, Death by a Thousand Cuts: The Fight Over TAXING INHERITED WEALTH 1 (2005).

136. Id. at 21, 51 (emphasis added).

137. See id. at 124-25.

138. See id. at 234
} 
individual, rather than national, interests. Although only $2 \%$ of the population paid estate taxes, more than half of the public incorrectly believed that the tax affected all taxpayers and that the tax was assessed on transfers to surviving spouses. ${ }^{139}$

Opponents of repeal could have advanced another version of the family frame, by highlighting that some of the money generated by the estate tax may support families, albeit only indirectly and through the government. Some, such as William Gates, Sr. and a coalition called Responsible Wealth, did argue that those leaving high-wealth estates would not have acquired their wealth without a strong, tax-supported public sector. ${ }^{140}$ But such an argument cannot be captured in a simple system frame. George Lakoff, the leading advocate of framing political issues through family metaphors, has not advocated a family frame for taxes, but rather suggests that progressives should frame taxes as "dues, paying your membership fee in America." ${ }^{141}$ Here the frame is a national membership organization, not the pervasive and powerful frame of family. Once conservatives framed the estate tax repeal as elimination of the "death tax" on family transfers, the outcome of subsequent debate was largely determined by system justification motives.

In the case of both affirmative action and the repeal of the estate tax, advocates framed system justifymg arguments to appeal to potential opponents. The brief of the military appealed to the national security concerns of conservatives. The arguments of the opponents of the estate task used the family frame to win support from people with no direct economic stake in the outcome. In both instances, advocates demonstrated the power of framing public policy issues in terms of the systems to which systcm justification motives may be directed.

\section{III}

\section{IMPLICATIONS OF SYSTEM JUSTIFICATION THEORY FOR LAW AND REGULATION}

The previous Part focused on how lawyers and advocates might use knowledge of SJT to be more effective within existing policy and legal regimes. SJT also has implications for the shape those policy and legal regimes should take. SJT has implications across a range of circumstances important to law and policy, from the circumstances in which factually innocent suspects will feel more motivated to confess, to the likely adherence

139. Id. at 125. There was likely also a "homo economicus with incomplete information" phenomenon at work: in $1999-2000,39-41 \%$ of Americans believed they were already within the top $1 \%$ of wealth or soon would be. Id. at 119 .

140. Id. at 168-71.

141. George Lakoff, Don't Think of an Elephant!: Know Your Values and Frame the Debate: The Essential Guide for Progressives 25 (2004). 
to norms important in environmental regulation or tax compliance. We leave determining the precise implications of SJT in such fields to those with more expertise and more pages in which to write. In this Part we aim only to illustrate how SJT might provide useful insights into topics of importance to doctrinal scholars, judges, and policy makers. We do so by examining some possible implications in two quite different areas: expected claiming rates in tort law regimes and expected behavior by insiders in instances of corporate wrongdoing. We do not mean to suggest that SJT has peculiarly powerful implications in these two areas. If people do possess powerful system justifying motives, as the science suggests they do, then it is difficult to imagine areas of doctrine in which the implicit assumptions of the doctrine about human motivation and behavior do not bear reexamination.

\section{A. System Justification Theory and Claiming Rates in Tort}

The policy goals underlying tort regimes depend on assumptions about whether disfavored behavior will lead to a legal claim. The process of "naming, blaming, and claiming" has framed analysis of this issue since an article by Felstiner, Abel, and Sarat described the sequence in its subtitle. ${ }^{142}$ In deciding whether to make a tort claim, the potential plaintiff always considers the possibility of just "lumping it,"143 particularly if she sees her unpleasant circumstances as part of the natural order of things. Similarly, the victim of a potential criminal battery is unlikely to report a crime if she regards the behavior as part of the "usual," even if not fully acceptable, pattern of relationships. The deterrent effects of tort and criminal law regimes depend upon claims making and crime reporting. Most current attempts to understand these phenomena look to demographic and other variations in claiming and reporting rates. None of these analyses, however, consider system justification motives, which may further help explain patterns of claiming and reporting.

\section{Claiming Fates for System-Implicating Claims}

As noted earlier, a "system" in SJT can refer to a family, a workplace, or the nation as a whole, but it always involves sustained differentiation or ordering of relations among the people and roles that comprise it. In social systems, the ordering may be by class, gender, caste, religious affiliation, or other indicators tied to expected roles and social power. Discrimination

142. William L.F. Felstiner et al., The Emergence and Transformation of Disputes: Naming, Blaming, Claiming..., 15 LAW \& Soc'Y REv. 631 (1980-1981) (discussing the process as an individual perceives an injury (naming), views the injury as a grievance (blaming), and files suit (claiming)).

143. The term, now common among law and society scholars, comes from William L.F. Felstiner, Influence of Social Organization in Dispute Processing, 9 L. \& Soc'Y REv. 63, 81 (1974) and refers to a decision not to seek a remedy for a perceived injury. 
claims, for example, invariably involve some objection to a de facto social order, whether in a workplace, a public school, or some other social context. Family systems are ordered by expected roles for family members and the relationships among them and, of course, vary widely across cultures. A domestic violence incident takes place, by definition, within a familial system as well as a societal system of gender relations (e.g., patriarchy). However, not every claim directly connects to a socially ordered system. Ordinary automobile accident negligence cases occurring between strangers, for example, do not usually implicate a social system.

SJT leads to two kinds of predictions about claiming rates. First, SJT suggests that claiming rates should be affected by whether or not the claim can be construed as a potential challenge to the current ordering of social relations and/or the legitimacy of the social status quo. We call these "system-implicating" claims. Second, system justification motives should tend to suppress claiming rates among the disadvantaged, who are likely to have internalized a depressed sense of entitlement, particularly with regard to system-implicating claims. Thus, SJT suggests that an internalized sense of entitlement should lead to higher rates of claiming among the advantaged. We now consider some of the existing evidence concerning these predictions. Examples of "system implicating" claims are discrimination claims and domestic violence claims, both of which challenge a putative social order, whether societal or familial.

Among the more striking findings of early studies on claiming were very low rates of claiming for discrimination. Miller and Sarat reported claiming rates for discrimination of $29 \%$, compared to rates of $80-95 \%$ for real estate or consumer grievances in the United States. ${ }^{144}$ Researchers reported similar statistics in Australia ${ }^{145}$ and in Canada. ${ }^{146}$ More recent work suggests that the claiming gap, though still significant, is not as great as earlier studies had estimated. ${ }^{147}$

SJT is compatible with other explanations for low rates of claiming in discrimination cases. Bumiller, for instance, argued that the processing of discrimination claims often gives mcentives to victims not to claim,

144. See Richard E. Miller \& Austin Sarat, Grievances, Claims, and Disputes: Assessing the Adversary Culture, 15 LAw \& SoC'Y REv. 525, 539-40 (1980). But see Herbert M. Kritzer et al., To Confront or Not to Confront: Measuring Claiming Rates in Discrimination Grievances, 25 LAW \& SOC'Y REv. 875, 880-82 (1991) (disputing the Miller \& Sarat methodology and finding that the claiming rate in the United States is closer to $57 \%$ ).

145. Jeffrey Fitzgerald, Grievances, Disputes \& Outcomes: A Comparison of Australia and the United States, I LAW IN ConTEXT 15, 47 (1983).

146. W.A. Bogart \& Neil Vidmar, Problems and Experiences with the Ontario Civil Justice System: An Empirical Assessment, in ACCESS to Justice: Bridges and Barriers (Allan C. Hutchinson ed., 1990).

147. See Kritzer et al., supra note 144, at 884 ("Complaining or otherwise asserting claims appears, overall, to be less likely in discrimination problems than in other kinds of problems, but the gap is much smaller than previous research has indicated."). 
because claiming may lead to a second round of victimization. ${ }^{148}$ Kaiser and Miller reported that members of disadvantaged groups who attribute negative events to discrimination are viewed as troublemakers by others. ${ }^{149}$ Both authorities and neutral observers are especially likely to punish people who complain of discrimination, suggesting that they, too, possess system justification motives. Although additional studies are necessary to clearly isolate the effects of potential claimants' system justification motives from other perceived risks of claiming, it seems clear that we should attend to the effects of system justification in evaluating claiming behavior or creating legal regimes to reduce discrimination.

The evidence regarding domestic violence reporting is mixed. SJT would predict lower reporting rates for violence between domestic partners than for violence between strangers. Early work by socio-legal scholars and advocates focused on the phenomenon of underreporting of domestic violence by women and possible explanations, including the lack of an adequate response by law enforcement. ${ }^{150}$ Analysis of more recent evidence suggests, however, that domestic violence reporting rates are now similar to reporting rates of similar violence between strangers. ${ }^{\text {IsI }}$ This change may reflect differences in methodology or a genuine change in the underlying phenomena, perhaps because of the success of the feminist movement in overcoming system-justifying biases enough to legitimize complaints and delegitimize the excuses of perpetrators. As in many other settings, the complexities of the situations and the difficulty of obtaining accurate information limit our ability to isolate the effects of system justification.

\section{Differential Claiming by Those Advantaged vs. Those Disadvantaged by a System}

According to SJT, people disadvantaged by a system can, paradoxically, be especially motivated to defend its legitimacy and integrity. A case in point is the depressed entitlement effect among women and members of other disadvantaged groups. Thus, we should see lower claiming rates by members of socially or economically disadvantaged groups compared to

148. Kristin Bumiller, The Civil Rights Society: The Social Construction of Victims 2 4 (1988).

149. Cheryl Kaiser \& Carol T. Miller, Derogating the Victim: The Interpersonal Consequences of Blaming Events on Discrimination, 6 Group Processes \& INTERgroup Rel. 227, 234 (2003).

150. See J. David Hirschel et al., Review Essay on the Law Enforcement Response to Spouse Abuse: Past, Present, and Future, 9 JuST. Q. 247, 253-54 (1992).

151. Richard B. Felson, Violence \& Gender Reexamined 89 (2002) (noting the possibility that "there are characteristics of partner violence that motivate as well as inhibit victim reporting" to explain why reporting rates between victims of crimes committed by strangers and victims of crimes committed by partners are the same); see also Matthew R. Durose et al., Family Violence Statistics: Including Statistics on Strangers and Acquaintances, in BUREAU OF Justice Statistics 2 (June 2005), available at http://www.ojp.usdoj.gov/bjs/pub/pdf/fvs.pdf (finding that the reporting rate for female and male victims is not significantly different). 
advantaged groups. As before, there may be other explanations, but the evidence is in accord with the predictions of SJT. For example, Helen Burstin and her colleagues examined 31,000 hospital records to evaluate the factors associated with the advancing of malpractice claims. They found, after controlling for severity of injury, that the poor and elderly were less likely to file malpractice claims than other groups. ${ }^{152}$

SJT also predicts relatively high claiming rates among those who are generally advantaged by a social system. Barry Goldman surveyed 439 terminated employees applying for unemployment benefits to determine whether they had made claims under discrimination laws. ${ }^{153}$ Goldman reported a "counter-intuitive finding" that terminated White employees were significantly more likely than their minority counterparts to advance discrimination claims. ${ }^{154}$ This finding is entirely consistent with SJT, which would predict underclaiming by the disadvantaged and overclaiming by the advantaged.

More work is necessary to isolate the effects of system justification processes from other potential causes of differential claiming rates, such as different levels of knowledge about the law and access to legal advice (although some of these factors are probably also related to system justification). However, SJT suggests that, particularly in the case of claims that question the fairness or legitimacy of valued social systems, we ought not to assume that every injured party will act as if he or she is aggrieved. Given the evidence regarding the importance of implicit processes in motivating behavior, and the specific evidence for the operation of system justification motives at an implicit level, it appears that some grievances may be unconsciously suppressed even before they are "named."155

\section{B. System Justification and Corporate Regulation}

Traditionally, corporate legal scholarship has relied on a rational choice model of CEOs, board members, corporate insiders, and auditors to examine the laws surrounding corporate compliance and regulation. More recently, legal scholars have introduced the insights of behavioral science to account for why corporate insiders may behave in ways not entirely explained by rational choice theory. For example, Donald Langevoort has used cognitive and motivational psychology to determine why, "[f]rom a rational standpoint,... would public companies ever deliberately lie to investors when, because they are neither buying nor selling stock in the

152. Helen R. Burstin et al., Do the Poor Sue More? A Case-Control Study of Malpractice Claims and Socioeconomic Status, 270 JAMA 1697 (1993).

153. Barry M. Goldman, Toward an Understanding of Employment Discrimination Claiming: An Integration of Organizational Justice and Social Information Processing Theories, 54 PERSONNEL Psychol. 361, 370-72 (2001).

154. Id. at 378 .

155. Greenwald \& Krieger, supra note 10. 
open market, there is nothing directly to gain?"156 Steve Bainbridge used insights from psychology to assess the benefits and risks of group decisionmaking by corporate boards, ${ }^{157}$ as well as the efficiency of mandatory disclosure rules. ${ }^{158}$ Robert Prentice examined how the array of well-known decision-making biases likely affects corporate auditors. ${ }^{159}$ These scholars have made a reasonable case that corporate law and regulation predicated on a rational choice model of behavior is likely to be, to some degree, ineffective or inefficient.

Scholars have not yet applied SJT to corporate law, although the theory has much to say about the motives and likely behavior of corporate insiders and others who may identify with their corporate clients (such as lawyers or auditors). To the extent that individuals identify with the corporate enterprise and accept the legitimacy of the corporate system, they will likely exhibit system-justifying behavior that is not economically rational. Moreover, motives will affect the behavior of not only corporate managers but also those further down the corporate ladder. For some corporate employees, particularly those most in control and with the most to lose, the immediate ego, group, and system justification motives all pull in the same direction. However, contrary to the predictions of rational choice theory, SJT suggests that system justification may inhibit reporting by low-level employees of the misconduct of superiors, even if they have been traditionally disadvantaged within the firm, and even when self-interest counsels otherwise.

SJT further suggests that system justification effects are likely to be most pronounced when the corporation itself is perceived to be at serious risk. Rational choice theories of deterrence assert that the threat of adverse consequences inhibits proscribed behavior. As we have seen, however, higher perceived system threats leads to more, not less, system justification. SJT thus warns that corporate insiders will be strongly motivated to deny, not only to others but also to themselves, the existence or validity of information that is potentially damaging to the firm. The result may be that it is often self-deception rather than conscious prevarication that misleads investors and regulators.

As Langevoort and others have pointed out, well-known cognitive phenomena, including confirmation bias, status quo bias, hindsight bias, and self-serving bias, may produce similar motivations to paint an overly

156. Donald C. Langevoort, Organized Illusions: A Behavioral Theory of Why Corporations Mislead Stock Market Investors (and Cause Other Social Harms), 146 U. PA. L. REv. 101, 106 (1997).

157. Stephen M. Bainbridge, Why a Board? Group Decisionmaking in Corporate Governance, 55

VAND. L. REV. I (2002).

158. Stephen M. Bainbridge, Mandatory Disclosure: A Behavioral Analysis, 68 U. CIN. L. REv. 1023 (2000).

159. Robert A. Prentice, The Case of the Irrational Auditor: A Behavioral Insight Into Securities Fraud Litigation, 95 Nw. U. L. REv. 133 (2000) 
optimistic picture of a firm's circumstances. ${ }^{160}$ Group justification motives may also inhibit reporting, to the extent that systems (e.g., the energy industry or the Enron Corporation) are closely related to social groups (e.g., Enron employees). What SJT highlights is that decision-making is embedded in psychological attachments to systems.

In the corporate world, some employees are more attached to their firm than others. Those who invest the most in their careers may identify most strongly with the corporation and defend its practices most fervently. Certainly, loyalty to the firm is highly prized among corporate managers and is a legal requirement of board members. Employees who demonstrate personal commitment to the firm will likely receive promotions over those whose attitudes suggest detachment or mixed loyalties. Thus, over time, the concentration of high system-justifiers at the top of the firm's hierarchy should increase. Given that the most meaningful (and private) corporate information also settles at the top, the additional effect of system-justifying motives on information disclosure provides an additional reason for concern.

SJT suggests that both corporate managers and regulatory regimes should focus on how features of institutional design may affect the operation of system justification motives. Corporate employees do not exist within a single, undifferentiated system of "The Firm." Employees are also located within subsidiaries, units, and local offices, and often other classification schemes; system justification motives may attach to any one or more of these subsystems. Although firms may spend a great deal of time and money promoting a unitary firm culture and attachment to the larger enterprise, an individual Enron employee may also be a member of a gas and oil group, an auditing team, the Galveston office, or the accounting profession. For those with stronger attachments to an audit team or the accounting profession, system justifying motives may actually promote disclosure rather than concealment.

Formal structural measures, such as requiring the institutional separation of auditing and accounting functions, can lessen the economic incentives for inaccurate disclosure by these actors. Such measures do not, however, insulate against the subtle pressures of group and system justification motives. During the collapse of Enron and Arthur Andersen, nominally independent auditors clearly came to see themselves as part of the system they were formally charged with monitoring:

Many of Andersen and Enron's top number crunchers took annual golf vacations together, making friendly bets on each round. They went on ski outings, schussing down the slopes together. Others

160. Donald C. Langevoort, Resetting The Corporate Thermostat: Lessons from the Recent Financial Scandals About Self-Deception, Deceiving Others and the Design of Internal Controls, 93 GEO. L.J. 285, 294-95 (2004). 
would sneak away from the office for Astros games at Enron Field and take turns buying margaritas at Mama Ninfa's, a local Mexican restaurant chain. They played fantasy football against each other over the office computers. ${ }^{161}$

There is substantial research on the psychological processes by which individuals come to develop loyalties toward other individuals, groups, and institutions, and to see themselves as part of one social system but not another. Experimental social psychology has demonstrated that people can develop attachments to, and prejudices in favor of, even experimentally created "minimal groups" comprised of individuals who have virtually nothing in common. ${ }^{162}$ Applying this research, there is good reason to expect that formal differences between employees and independent auditors, or between "inside" and "outside" directors, will not automatically provide protection against the effects of system justifying processes and other sources of bias. SJT suggests that organizations should ensure actual social distance, and not mere formal separation of functions, as between the auditors, inspectors general or internal affairs officers, and those they monitor.

Under ordinary circumstances, other motivations, including fear of punishment arising from securities laws and other regulation, may swamp pressures to withhold disclosure. But when the corporation is most at risk, and potentially withheld or discounted information is therefore most significant to the market, system justification motives are likely to be most powerful. Furthermore, an effective monitoring and oversight apparatus designed to restrain self and group interests by increasing the threat of detection may actually increase the salience of system justification motives. SJT thus suggests that it is crucial to frame monitoring and oversight functions not as inquisitorial activities but as an unexceptional, routine part of corporate life, and thus part of the status quo to be defended.

IV

\section{A Behavioral Realist Prognosis For Behavioral Realism}

Legal scholarship and social scicnce research, as well as law and policy, are situated in social systems. SJT is thus among those few theories with self-referential reach; it says something about how audiences will

161. Alexander Delroy, Ties to Enron Blinded Anderson; Firm Couldn't Say "No" to Prized Client; Bound by Mutual Interests and Money, Managers Buckled Before the Houston Energy Trader Even When Deals Seemed Questionable, CHI. TriB., Sept. 3, 2002, at 1.

162. See Itesh Sachdev \& Richard Y. Bourhis, Status Differentials and Intergroup Behavior, 17 Eur. J. SOC. Psychol. 277 (1987); Henri Tajfel, Experiments in Intergroup Discrimination, 223 Sci. AM. 96, 101-02 (1970) (finding that "[w]hen the subjects had a choice between profit for all and for their own group combined, as against their own group's winning more than the outgroup at the sacrifice of both of these utilitarian advantages, it was the maximization of difference that seemed more important to them."); Henri Tajfcl et al., Social Categorization and Intergroup Behaviour, I EuR. J. Soc. Psychol. 149, 172-76 (1971). 
receive ideas like system justification. $\ln$ this Part we discuss the prospects for one very promising area in which behavioral realists are hard at work: the incorporation of scientific insights on implicit bias into law and some of the processes, themselves implicit, that may impede the acceptance of these findings.

We can expect both ego and group justification motives to animate resistance to theories of implicit social cognition. The notion that meaningful mental events occur outside the reach of conscious awareness and personal control challenges basic Westcrn assumptions about rationality and individual autonomy. $1 \mathrm{t}$ is also difficult for most of us to accept that groups to which we belong may harm (or be harmed by) others because of automatic and uncontrolled processes. We can thus expect both ego justification and group justification motives to animate a certain level of resistance to theories of implicit social cognition, especially in emotion-laden areas such as racial or gender bias.

System justification motives will likely provide further resistance to changing extant conceptions of bias and prejudice. The motive to defend the status quo extends to the status quo in science, with respect to both folk and professional scientific theories. That science is an inevitably human and social enterprise has been a commonplace at least since the 1962 publication of Thomas S. Kuhn's The Structure of Scientific Revolutions and forms the premise of an entire field, the sociology of science. ${ }^{163}$ Although many scientific institutions (including journals and professional societies) are notoriously slow to change, science is often assumed to be innovative. Krieger and Fiske write in this volume, for example, that "the empirical social sciences construct and use theories of human behavior with an almost hopeful eye toward their eventual emendation, supplementation, or even outright replacement." 164 The empirical study of scientific practice, however, suggests that despite an explicit allegiance to Karl Popper ${ }^{165}$ and standard conceptions of scientific method, scientists are not immune from their attachments to prevailing theories and the professional hierarchies they sometimes engender, even in the face of significant disconfirming evidence. ${ }^{166}$

Unlike scientific psychology, folk psychology (including the folk psychology of scientists and legal scholars) lacks the norms of empiricism and

163. See, e.g., Robert K. Merton, The Sociology of SCIEnCE: Theoretical and EMPirical INVESTIGations (1973). Just how human and how social is controversial. See Steve Fuller, Philosophy of Science and 1Ts Discontents 7 (2d ed. 1993) (eontesting this view and referring to the sociology of scicntific knowledge as "the great pretender").

164. Linda Hamilton Krieger \& Susan T. Fiske, Behavioral Realism in Employment Discrimination Law: Implicit Bias and Disparate Treatment, 94 CALlF. L. REv. 998 (2006).

165. See Karl R. Popper, The Logic of Scientific Discovery (1959).

166. In addition to Kuhn, cited in the text, see Donald T. Campbell, From Evolutionary Epistemology Via Selection Theory to a Sociology of Scientific Validity, 3 Evolution \& Cognition 1, 29 (1997). 
openness to change. In every culture, the folk philosophy of science is "common sense," which may be common but is not necessarily sensible. Since so much of the behavioral realist project conflicts with folk psychology, it faces sources of resistance that other theories may not encounter. It is easier for most laypeople, including judges, to accept new theories in genetics or economics, because we have such poorly formed folk theories in these areas. But psychology is a different matter. Developing a tacit theory of why other people behave as they do is part of the process of becoming a socialized human being in every culture. Indeed, the inability to ascertain the intentions and beliefs of others is the mark of a serious disability such as autism. ${ }^{167}$

\section{A. Formalism: Stare Decisis and Prudential Reasons for Law to Lag Behind Science}

Although much of the science of implicit social cognition is now established well beyond the standard Daubert v. Merrell Dow Pharm., Inc. ${ }^{168}$ would require for its admission at trial, and although our colleagues have been bringing it to the attention of both legal scholars and the judiciary at least since Linda Hamilton Krieger's The Content of Our Categories, ${ }^{169}$ the judiciary has paid remarkably little attention in the decade since. ${ }^{170}$ There are probably several reasons for this neglect, some of them entirely rational and prudential. First, the courts may be deliberately ignoring developments

167. Uta Frith, Autism: Explaining the Enigma 120-21 (2d ed. 2003).

168. Daubert v. Merrell Dow Pharm., Inc., 509 U.S. 579 (1993). In determining whether to admit expert scientific evidence, federal courts are tasked with assessing "whether the reasoning or methodology underlying the [proffered expert] testimony is scientifically valid and of whether that reasoning or methodology properly can be applied to the facts in issue." Id. at 592-93. In making this determination, the Supreme Court standard requires evaluation of several factors, including: (1) "whether a theory or technique ... . can be (and has been) tested," (2) "whether the theory or technique has been subjected to peer review and publication," (3) "the known or potential rate of error,"; and (4) the "degree of acceptance within [the relevant] community." Id. at 593-94 (quoting United States v. Downing, 753 F.2d I224, 1238 (3d Cir. 2985)). Whatever dispute there may be about how implicit biases are at work in a given case, there is very little doubt that implicit biases exist and affect behavior.

169. Krieger, supra note 52.

170. A WESTLAW search found 290 journal articles eiting Krieger's piece, and only one federal case taking note of the science Krieger first brought forth to a legal audience: a federal district court order denying a challenge to the alleged de facto exclusion of certain racial groups from service as grand jury foreperson, Chin v. Runnels, 343 F. Supp. 2d 891, 906-07 (2004). WESTLAW search, JLR, ALLFED and ALLSTATES databases (September 5, 2005). Krieger's later piece, Civil Rights Perestroika: Intergroup Relations after Affirmative Action, 86 CALIF. L. REv. 1251 (1998) was cited by Justice Ginsberg in her concurrence in Grutter $v$. Bollinger for the proposition that "[i]t is well documented that conscious and unconscious race bias, even rank discrimination based on race, remain alive in our land, impeding realization of our highest values and ideals." 539 U.S. 306, 345 (2003) (Ginsburg, $\mathbf{J}$., concurring). There has been some effort to introduce this science at the trial court level in employment discrimination cases. For a good summary, see William T. Bielby, Can I Get a Witness? Challenges of Using Expert Testimony on Cognitive Bias in Employment Discrimination Litigation, 7 EMP. RTs. \& EMP. PoL'Y J. 377 (2003). 
in social psychology pursuant to standard principles of stare decisis. Full acceptance of these implications would destabilize an entire body of antidiscrimination law that has been erected on assumptions that discrimination results from explicit, conscious, deliberative processes. Stability in the law serves several important purposes, including protection of those who have relied on precedent in shaping their lives and businesses.

Although a dramatic change in factual assumptions may lead to the reversal of precedent, such reversals are rare, particularly in constitutional adjudication in highly controversial areas. In declining to overturn Roe $v$. Wade, ${ }^{171}$ the plurality opinion in Planned Parenthood of Southeastern Pennsylvania v. Casey ${ }^{172}$ could cite only the examples of West Coast Hotel v. Parrish, ${ }^{173}$ overruling Lochner v. New York, ${ }^{174}$ and Brown v. Board of Education, ${ }^{175}$ overturning Plessy v. Ferguson. ${ }^{176}$ The Casey plurality emphasized that respect for precedent and majority opinion is core to the legitimacy of the Court itself:

The Court must take care to speak and act in ways that allow people to accept its decisions on the terms the Court claims for them, as grounded truly in principle, not as compromises with social and political pressures having, as such, no bearing on the principled choices that the Court is obliged to make. Thus, the Court's legitimacy depends on making legally principled decisions under circumstances in which their principled character is sufficiently plausible to be accepted by the Nation. ${ }^{177}$

Thus, the sheer pervasiveness of folk psychology among the populace may discourage the judiciary from joining with science in getting too far ahead of the people, particularly when it comes to the deepest cultural beliefs and practices. But there are other plausible explanations for the judiciary's resistance to findings of implicit cognition.

\section{B. Hypotheses from Legal Realism and Behavioral Realism}

A traditional legal realist, a critical legal scholar, or even an ordinary cynic could observe that updating the factual basis of discrimination law to incorporate the science of implicit bias will likely increase the odds for plaintiffs in discrimination cases. Assuming that few federal judges have been appointed in recent years to advance civil rights, it is not surprising that judges lack enthusiasm for altering legal doctrine to favor plaintiffs in Title V1I cases. For traditional legal realists, such outcome-driven

171. 410 U.S. $113(1973)$.

172. Planned Parenthood of Southeastern Pennsylvania v. Casey, 505 U.S. 833, 860-64 (1992).

173. 300 U.S. $379(1937)$.

174. 198 U.S. 45 (1905).

175. 347 U.S. 483 (1954).

176. 163 U.S. $537(1896)$.

177. Casey, 505 U.S. at 865-66. 
jurisprudence is the product of a cold, intentional calculus of results. lronically, legal realists would thus adopt a tacit judicial psychology that is quite similar to the folk psychology of discrimination that now pervades antidiscrimination doctrine.

A behavioral realist assessing the prospects for behavioral realism in the judiciary will attend to the possibility that cognitive dissonance, implicit biases, and system justification motives affect judges, just like the rest of us. Behavioral realism challenges the rational actor models upon which both folk psychology and the dominant free market ideologies in law are based. One might expect some resistance, then, to incursions by behavioral realists into any area of law, even those that have relatively little to do with power and privilege.

But when behavioral realism intrudes on antidiscrimination law, it threatens to upset not only existing doctrine but also existing social hierarchies. Current antidiscrimination jurisprudence is itself part of the ideological apparatus that both restrains and justifies social hierarchy. Title VII law says not only what discrimination is, but also what it is not, providing both symbolic and sometimes legal "safe harbors" from those claiming discrimination. ${ }^{178}$ In the same way that a jury verdict of "not guilty" is often misread as "innocent," a judicial declaration of "not discriminatory" is understood to sanction an institutional or organizational practice as normal, acceptable, and legitimate. Common practices leading to radical inequality are thus readily justified, especially if they are not marked by blatant expressions of prejudice. ${ }^{179}$

Counterintuitively, advocates for members of disadvantaged (as well as advantaged) groups are also likely to resist some of the implications of implicit bias theories. The folk psychology of intentional discrimination that underpins antidiscrimination law also provides some psychological benefit to those who are disadvantaged by discrimination. If discrimination includes only conscious, intentional discrimination, then discrimination is likely to be relatively rare. Moreover, intentional discriminators are more easily identified and punished or avoided. On the other hand, if discrimination is the product of seemingly pervasive implicit biases, then both refuge and remedy become problematic, a realization that can come only at substantial psychological cost. It is painful to believe that one is the frequent

178. In Faragher v. City of Boca Raton, 524 U.S. 775 (1998) and Burlington Industries v. Ellerth, 524 U.S. 742 (1998), the Supreme Court established an affirmative defense to employment discrimination claims based on a "hostile work environment" if the employer shows that it has an antidiscrimination policy, and provides training and a grievance procedure.

179. Such practices or behavior can be the product of unacknowledged and uncontrolled implicit bias, or of institutional arrangements that reflect the consequences of past discrimination. See, e.g., lan F. Haney López, Institutional Racism. Judicial Conduct and a New Theory of Racial Discrimination, 109 YALE L.J. I7I7, I757-60 (2000) (describing how the process of having judges nominate grand jurors from among their acquaintances resulted in the exclusion of Latina/os from the Los Angeles Grand Jury). 
victim of social injustice or that the entire system on which one depends is corrupt. Studies consistently find that individual members of disadvantaged groups believe that they experience less discrimination than do other members of their group. ${ }^{180}$ Apparently, the denial of personal discrimination serves a palliative function.

Antidiscrimination activists, advocates, and scholars may also be resistant to incorporating the science of implicit bias and system justification into their work. For these individuals, working within the intentional discrimination model (the legal status quo) has its own psychic rewards. It is much more satisfying to defeat evil than to deal pragmatically with the banal. Advocates may also take comfort in the conviction that the disadvantaged share their progressive values and are motivated by self-interest to support the cause. Evidence of system justification and implicit outgroup preferences is not welcome news for those seeking change.

Moreover, although advocates often strive to challenge racial and other existing hierarchies, they work within an established system of understandings and practices developed over many years. The new science challenges the assumptions of some of these practices. Modern antidiscrimination legal advocacy took shape in the work of the NAACP Legal Defense Fund leading to Brown v. Board of Education. This work gave rise to a professional hierarchy of antidiscrimination work in which there could be no higher calling than helping to shape the decisions of the United States Supreme Court. This conviction grew even as the empirical evidence indicated that Brown itself had limited effect in the segregated schools of the South. It is conceivable that scientific work on implicit bias will find a more receptive audience among legislators, regulators, or firms than among federal judges. However, legal advocates and scholars may also be reluctant to abandon their own familiar script for how progress comcs about, in part because of their own historical role in that script.

In the end, of course, this outline of the challenges facing the project of behavioral realism, particularly in areas that touch on social justice concerns, are hypotheses rather than conclusions. This Symposium, which is both inspired by and reliant on behavioral research findings, begins an experiment that will determine whether our hypotheses are well-founded. The outcome of our experiment is important for reasons that are not merely academic. Whether we can gain any ground in the struggle against discrimination and injustice ultimately depends on how well we understand ourselves, others around us, and the social systems that we have inherited from the past. The outcome also depends on how well we can incorporate

180. See Faye Crosby, The Denial of Personal Discrimination, 27 AM. BEHAV. SCl. 371 (1984). The phenomenon has a name: PGDD, for "personal/group discrimination discrepancy." See, e.g., Kimblery A. Quinn et al., The Personal/Group Discrimination Discrepancy: The Role of Informational Complexity, 25 Personality Soc. Psychol. Bull. 1430 (1999). 
the lessons of behavioral research into our scholarship, our advocacy, and our lives. 